http://dx.doi.org/10.11646/zoosymposia.13.1.19

http://zoobank.org/urn:Isid:zoobank.org:pub:4E68A0B8-CEA9-4530-9C44-617C3D27AC16

\title{
The Columbellid species of the northeast Pacific coast from the Aleutian Islands to Cedros Island, Baja California (Neogastropoda: Columbellidae)
}

\author{
MARTA J. DEMAINTENON \\ Department of Marine Science, University of Hawaii at Hilo, 200 W. Kawili St., Hilo, HI, USA, 96720. Email: demainte@hawaii.edu
}

\begin{abstract}
The neogastropod family Columbellidae is a diverse cosmopolitan group of small marine snails, with its greatest diversity in the tropics. They are represented in high latitudes, but the columbellid fauna of higher latitudes tends to be much less well documented. The present paper documents the nearshore columbellid fauna of the northeastern Pacific Ocean, from the Aleutian Islands to Cedros Island, near the dividing point between Baja California and Baja California Sur. It is based on work by J.H. McLean, and completed posthumously. Examination of the regional columbellid collections in the Natural History Museum of Los Angeles County and the Santa Barbara Museum of Natural History has resulted in 24 species in eight genera, of which four new species and one new genus are described herein. The present paper focuses on dry shell material.
\end{abstract}

Key words: Columbellidae, Caenogastropoda, new species, new genus, northeast Pacific

\section{Introduction}

Columbellid gastropods comprise a diverse group of active, mostly epibenthic marine snails, most small (less than $20 \mathrm{~mm}$ ) in size and often very common and /or diverse where they occur. They can be found in all coastal depths and a wide diversity of marine habitats. Most are opportunistic generalist carnivores.

Columbellid shells are usually biconic with spiral or axial sculptural elements, lacking spines or other processes. They generally resemble small buccinids, however some columbellid taxa strongly resemble members of other families, including conids, terebrids, mitrids or strombids. The one true diagnostic feature for the family is the form of the radular teeth (Radwin 1977), which have a unique stenoglossate morphology including an acuspate rectangular center plate and pincer-like lateral teeth that rotate on narrow bases. Columbellid taxonomy and relationships have since been based on characters of the shell and (to a lesser degree) the radula (e.g. Wilson 1994).

The columbellid fauna of the northeast Pacific has up to now been poorly studied. The fauna is surprisingly speciose, with 24 species in eight genera covered herein. Two genera, Amphissa and Exaesopus, are essentially endemic to the region. The majority of northeast Pacific columbellid species were described by Augustus Addison Gould and Philip Pearsall Carpenter in the mid-1800's, and William Healey Dall in the early 1900s. Later references added only few, and the diversity has remained relatively unchanged. Oldroyd (1927) listed 29 species and subspecies in five genera; a number of these have been synonymized since (e.g., Grant \& Gale 1931, Abbott 1974, McLean 1996). McLean (1996) reported five species in three genera from the Santa Maria Basin and the Santa Barbara Channel. The present manuscript includes four new species and one new genus originally identified by J.H. McLean. At this point, the systematic relationships of the Columbellidae have not been robustly addressed, so the included species are listed in alphabetic order by genus. 


\section{Materials and Methods}

This manuscript was originally largely written by Jim McLean, based on his many years of experience with the molluscan fauna of the northeast Pacific. I have re-edited it based on my understanding of worldwide Columbellidae. The material that forms the basis for this includes primarily the dry Recent Mollusca collections of the Natural History Museum of Los Angeles County, and the Santa Barbara Museum of Natural History, with reference to relevant type material there and elsewhere. The range of interest is the fauna from the Aleutian Islands, Alaska, in the north to Cedros Islands, Baja California, in the south.

Measurements of shells were taken along the coiling axis, from the apex to the tip of the columella, or the lower edge of the aperture if that projected beyond the columella. Maximum width was taken across the penultimate whorl to avoid flared aperture edges. Measurements were taken using a Vernier caliper accurate to $0.05 \mathrm{~mm}$, or for very small specimens, an ocular micrometer mounted in an Olympus SZX12 stereomicroscope. Teleoconch whorl counts vary relatively little in adult columbellids due to their determinate growth; these were taken from the protoconch/teleoconch boundary for the teleoconch. Protoconch whorl counts were taken from the origin of the suture at the apex. Photographs were taken using an Optronics digital camera mounted on the Olympus stereomicroscope.

\section{Repositories:}

$\begin{array}{ll}\text { IMBV } & \text { Institute of Marine Biology, Vladivostok, Russia } \\ \text { LACM } & \text { Natural History Museum of Los Angeles County, Los Angeles, CA, USA } \\ \text { MCZ } & \text { Museum of Comparative Zoology, Harvard University, Cambridge, MA, USA } \\ \text { NHMUK } & \text { Natural History Museum, London, United Kingdom } \\ \text { RM } & \text { Redpath Museum, McGill University, Montreal, Canada } \\ \text { SBMNH } & \text { Santa Barbara Museum of Natural History, Santa Barbara, CA, USA } \\ \text { USNM } & \text { United States National Museum of Natural History, Smithsonian Institution, Washington, DC, } \\ & \text { USA }\end{array}$

\section{Taxonomy}

\section{Columbellidae Swainson, 1840}

Diagnosis. Shell generally 5-25 mm long with determinate growth, biconic to terebriform; labial edge usually thickened, denticulate within in adults; columella smooth or weakly plaited, siphonal canal short, usually with shallow posterior canal along aperture edge. Animals colorful, long siphon, eyes large, foot long, narrow, elastic. Operculum corneous, usually drop-shaped. Radula stenoglossate, with rectangular, acuspate center plate; sigmoid, generally unicuspid laterals having 2-4 secondary cusps along inner edge.

Remarks. The primary distinguishing feature of the columbellids is the form of the radula; however radulae were not available for most of the material investigated herein.

\section{Genus Aesopus Gould, 1860}

Aesopus Gould, 1860: 383. Type species (M): Aesopus japonicus Gould, 1860. Japan.

Diagnosis. Shell 4-14 mm long, cylindrical to pupoid with shallow suture; aperture short, suture descending on last half whorl; labial edge denticulate or smooth within, usually extends past tip of columella; columella smooth with heavy anterior callus, some with transverse ridges; siphonal canal short; shell usually with fine spiral grooves.

Remarks. Gould (1860: 383) in his description called attention to the "curious curve of the suture near the posterior angle of the aperture, as if it had been drawn backward, thereby pulling back this angle and curving the last whorl downward." The pupoid shape, fine spiral sculpture and descending suture are the most diagnostic features for this genus, which has about 33 nominal species worldwide (MolluscaBase 2018), mostly in the tropics. 
Aesopus benitoensis n. sp.

(Figure 1B)

Type material. Holotype LACM 3612 (LACM station 1941-30 = Velero III 1250-41), 44-49 fms [81-90 m], San Benito Islands, Baja California $\left(28^{\circ} 17.3^{\prime} \mathrm{N}, 115^{\circ} 35.7^{\prime} \mathrm{W}\right), 26$ February 1941; $5.2 \mathrm{~mm}$ long. 2 paratypes LACM 3613, from type locality.

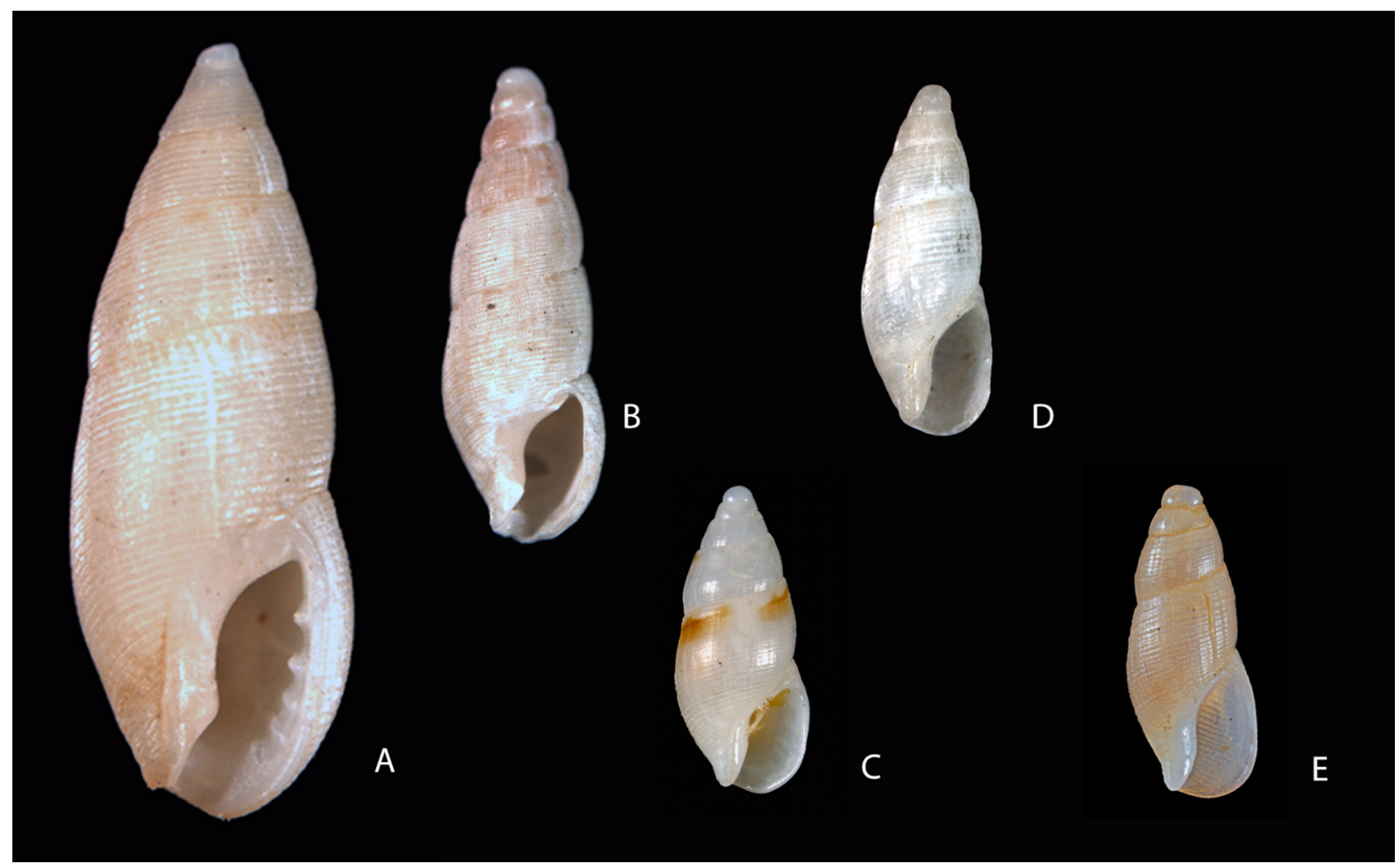

FIGURE 1. Aesopus species to scale. A. Aesopus chrysalloideus (Carpenter, 1866), dredged off San Diego, California (LACM 172881), 8.5 mm. B. Aesopus benitoensis n. sp. Holotype (LACM 3612, LACM station 1941-30) 81-90 m, San Benito Islands, Baja California. 5.2 mm. C. Aesopus myrmecoon Dall, 1916, Puerto San Carlos, Magdalena Bay, Baja California Sur (SBMNH 464124), 3.3 mm. D-E. Aesopus sanctus Dall, 1919. D. San Pedro, Los Angeles County, California (LACM 152209), 3.9 mm. E. Doheny Beach, Dana Point, Orange County, California (SBMNH 464125), $3.4 \mathrm{~mm}$.

Etymology. Named for the San Benito Islands, where it was found.

Description. Shell 5-6 mm long. Shell, narrow, width about 0.3 times length; $4-5$ teleoconch whorls, aperture small. Sculpture of narrow spiral grooves crossed by rough growth lines, causing finely reticulate sculpture. Off-white, pinkish toward apex, slight brown spots on subsutural cord. Weak labial lirae behind aperture edge, no columellar denticles. Anterior edge of columellar callus protrudes. Protoconch white to pinkish, blunt, 1.5 whorls with no velar sinus.

Distribution. Known only from the type locality.

Remarks. Aesopus benitoensis is proportionately taller and narrower than other regional species, with one more teleoconch whorl, a smaller aperture and unique reticulate sculpture.

Aesopus chrysalloideus (Carpenter, 1864)

(Figure 1A)

?Amycla chrysalloidea Carpenter, 1864: 613, 662, not figured. 1866: 223. Type. Syntype USNM 14953. Shoal water, San Diego, California, J.G. Cooper. $8.3 \mathrm{~mm}$ long.

Aesopus idae Bartsch, 1918: 79, not figured. Types. "types at present in Oldroyd's collection;" whereabouts unknown. San

Pedro, California, Pleistocene. 
Description. Shell 7-10 mm long, teleoconch whorls seven, profile slightly convex, sutures barely impressed; width about one-third length; ivory with narrow, interrupted white band just below suture; sculpture of fine spiral grooves; outer lip strongly denticulate within, parietal wall sometimes with three denticles, anterior callus protruding slightly. Protoconch broken in all specimens investigated, but appearing multi-whorled, with shallow velar sinus.

Distribution. Santa Monica, Los Angeles County, to San Diego, California; 10-25 m. Uncommon, not collected in recent years.

Remarks. The type lot of $A$. chrysalloidea was described by Palmer (1958) as consisting of five syntypes; the USNM online catalog lists just a holotype. Because Carpenter (1864) did not explicitly refer to a single specimen, the USNM specimen cannot be considered a holotype, but is a syntype. It is unknown whether Palmer (1958) was correct in indicating five syntypes, and whether four syntypes have been lost.

This species is recognizable because it is two or three times larger than other northeast Pacific Aesopus species. Carpenter gave it minimal treatment in 1864 (name only on p. 613 and a one-line description on p. 664), then described it completely in 1866 . The few specimens in collections are mostly subfossils, but the description in 1866 reports living specimens on sand at $8 \mathrm{fms}$. [14.6 m].

Aesopus myrmecoon Dall, 1916

(Figure 1C)

Aesopus myrmecoön Dall, 1916: 27, not figured. Type. Holotype USNM 105498. Point Abreojos, Baja California, H. Hemphill. $4.1 \mathrm{~mm}$ long.

Description. Shell 3-5 $\mathrm{mm}$ long, with four teleoconch whorls; profile convex, sutures barely impressed; glossy white with tan blotches; aperture edge not denticulate within; sculpture of fine, dense spiral grooves; protoconch unsculptured, white, 1.5-2 whorls, bluntly conic, no velar sinus.

Distribution. San Pedro, Los Angeles County, California, to Magdalena Bay, Baja California Sur. Subtidal to $10 \mathrm{~m}$. Rare.

Remarks. This species is wider relative to the length than others in the region, with a larger aperture and different color pattern. It is rare in collections, and I have only seen two lots from outer Baja and Baja California Sur. Though Dall (1916) reported the species from San Pedro south, it may prove to be restricted to a more southern distribution.

Aesopus sanctus Dall, 1919

(Figure 1D-E)

Aesopus sanctus Dall, 1919: 250, not figured. Type. Holotype USNM 308958. Bahía Todos Santos, Baja California, C.R. Orcutt. $4.3 \mathrm{~mm}$ long.

Description. Shell 3.5-5 mm long, with 3-4 teleoconch whorls; width/length ratio about 0.4; profile convex, sutures barely impressed; light pinkish brown, sometimes with brownish spots below suture; aperture edge not denticulate within; sculpture of fine spiral grooves, less developed on early whorls; protoconch unsculptured, white or off-white, 1.3-1.5 whorls, bluntly conic, no sinus.

Distribution. San Pedro, Los Angeles County, California, to Gulf of California (Keen 1971). Subtidal to $50 \mathrm{~m}$. Uncommon.

Remarks. This species resembles $A$. chrysalloideus, but is much smaller and relatively narrower. It is similar to $A$. benitoensis, but wider relative to its length with a larger aperture, fewer teleoconch whorls and no axial sculpture. Similar specimens have been collected to the south as far as Ecuador but need to be investigated in greater detail.

Not included. Aesopus goforthi Dall, 1912 (pp. 127-128, not figured). Holotype, USNM 249624. Dall reported that this single specimen was 'supposedly collected at Monterey' by W.C. Goforth. It does not conform to Aesopus, but slightly resembles species of Mazatlania, a columbellid genus known from further south. It bears no relation to any known species and nothing like it has been collected in the region since. The $12 \mathrm{~mm}$ long specimen appears also to be immature, or the aperture may be damaged. Given its uncertain affinities and location of collection, I do not include it as part of the regional fauna at this time. 
Alia H. \& A. Adams, 1853: 183. Type species (SD, Chenu 1859: 211): Columbella unifasciata Sowerby, 1832. Chile.

Diagnosis. Shell biconic, about twice as long as wide, length 6-12 mm (Radwin 1977); suture shallow; body whorl slightly shouldered to keeled; labial and parietal edges of aperture denticulate; protoconch conical, multiwhorled, unsculptured.

Remarks. H. \& A. Adams (1853) did not give a basis with which to differentiate members of Alia from Mitrella, both considered subgenera of Columbella, but restricted it to six nominal east Pacific coastal species, which have since been synonymized under three names (Alia carinata, Alia unifasciata, Mitrella gausapata). Both of the Alia species are thick shelled and slightly shouldered near the aperture, with denticles on both the labial edge and the parietal wall. Mitrella gausapata has been classified in several genera, see discussion under that species.

\section{Alia carinata (Hinds, 1844)}

(Figure 2A-D)

Columbella carinata Hinds, 1844 [1844-45]: 39, pl. 10, figs 15-16. Types. Three syntypes, NHMUK 1844.9.23.18-20. Bodegas and San Diego, California, $7 \mathrm{fms}[13 \mathrm{~m}]$ or less, Sir E. Belcher; one adult, $7.5 \mathrm{~mm}$, two subadults $6.9,7.2 \mathrm{~mm}$

Columbella (Astyris) carinata californiana Gaskoin, 1852: 12-13, not figured. Type. Syntypes. Whereabouts unknown. Sandeago [= San Diego], California, Cuming Collection.

?Nitidella gouldii Carpenter in Gould \& Carpenter, 1857: 208, not figured. Type. Holotype, MCZ 169463. Santa Barbara. E. Jewett.

Columbella hindsii Reeve, 1858: vol. 11, pl. 23, fig. 143a,b. Type. Four syntypes NHMUK 1966612. [no type locality given]. Alia callimorpha Dall, 1919: 330, not figured. Type. Holotype USNM 271491. San Diego, C.R. Orcutt.

Description. Shell length 6-11 mm; more strongly carinated individuals usually smaller. Teleoconch with 56 whorls. Body whorl slightly shouldered near aperture to strongly keeled (keel usually lighter in color than rest of shell); whorls variably inflated; outer lip sinuous; periostracum smooth; color usually yellow-brown to dark brown, often with white and/or darker brown mottling; labial edge frequently dark brown. Aperture edge in adults with labial denticles; about three irregular denticles on parietal wall, sometimes paler in color. Protoconch broadly conical, unsculptured, about three whorls, with velar sinus, often purple in color; usually eroded in adults.

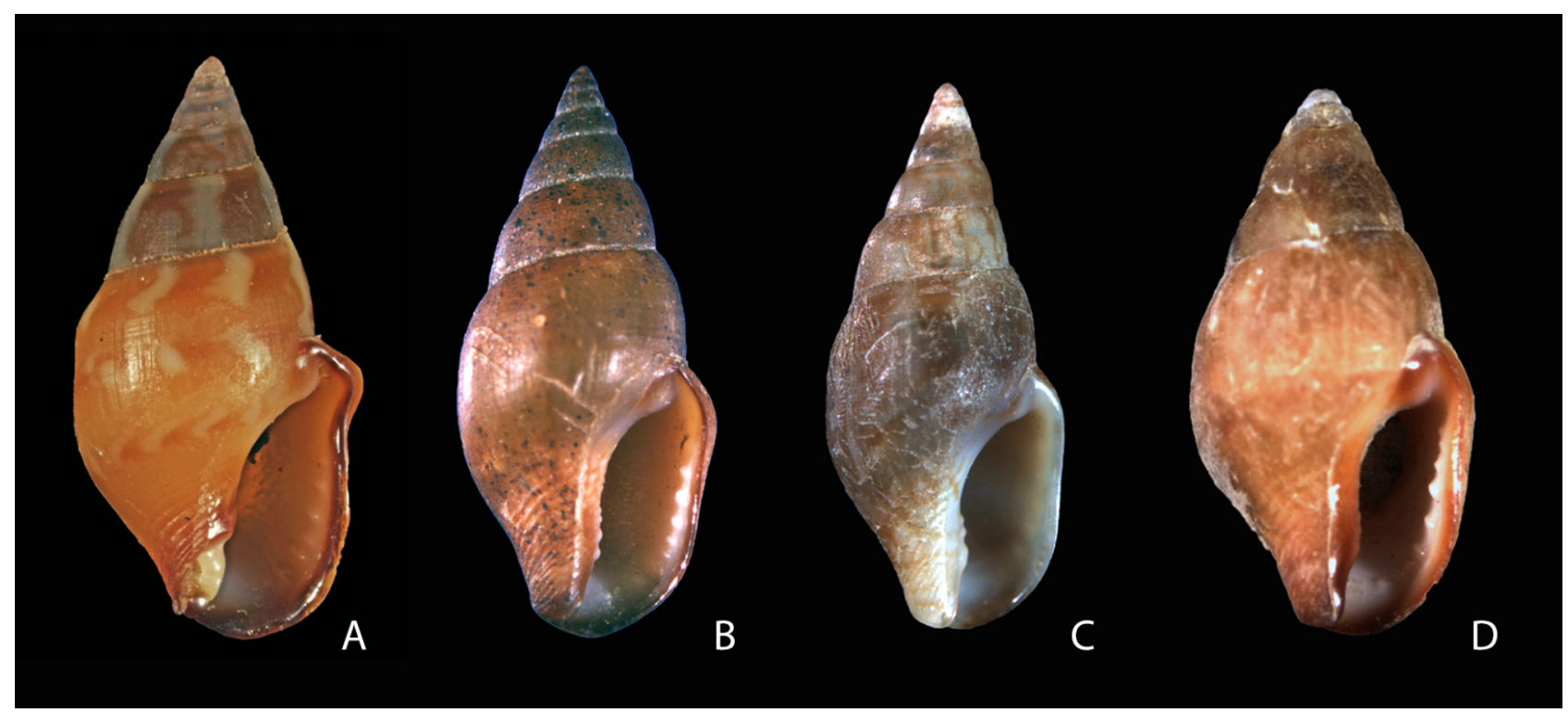

FIGURE 2. Alia carinata (Hinds, 1844). A. Intertidal on surfaces of rocks, $1 / 4 \mathrm{mi}$ of Malibu Pier, Los Angeles County, California (SBMNH 4057), 7.7 mm. B. 1 m, S side Kenai Peninsula, Alaska (LACM 1985-342.11), 9.4 mm. C. Intertidal, Heceta Island, Alexander Archipelago, Prince of Wales County, Alaska (LACM 1971-231.13), 8.0 mm. D. Tacoma, Pierce County, Washington (LACM 161252), $9.8 \mathrm{~mm}$. 
Distribution. Kenai Peninsula, Gulf of Alaska, to Abreojos Point, Baja California. Very common near surf grass and on rocks and algae from intertidal to subtidal depths.

Remarks. This species is variable in size and shape as well as color and pattern. Specimens with pronounced shoulder carinae are usually smaller. The three NHMUK syntypes are all similar, being small specimens about $7 \mathrm{~mm}$ long with strong carination, red-brown in color without pattern, with a light colored carina, dark brown aperture edge and siphonal canal, and dark purple-brown spire.

\section{Genus Amphissa H. \& A. Adams, 1853}

Amphissa H. \& A. Adams, 1853: 111. Type species (SD, Dall 1871: 111): Buccinum corrugatum Reeve, 1846, non Brocchi, 1814 [= Amphissa columbiana Dall, 1916]. Puget Sound.

Diagnosis. Shell 10-30 mm long in adults, buccinoid; high-spired, whorls convex, deep suture; columella smooth or with low plications, siphonal canal short, sculpture of axial ribs, incised spiral grooves or cords; labial edge barely thickened, dentate or lirate within; protoconch multiwhorled, sculptured.

Remarks. Amphissa is a characteristic genus of the cool waters of the northeastern Pacific, where there are two nearshore species and four from deeper water. There is also a single nominal species that occurs in the North Atlantic, and one in the southwest Atlantic, which will likely prove to be unrelated.

\section{Amphissa bicolor Dall, 1892}

(Figure 3B)

Amphissa bicolor Dall in Williamson, 1892: 213-214, pl. 20, fig. 4. Type. Lectotype (designated by McLean 1996: 110, fig. 1.22D) USNM 106877. RV Albatross Sta. 3187, off Point Sur, Monterey County, California, mud, 298 fms [545 m], 13.8 mm long.

Description. Shell to $16 \mathrm{~mm}$ long, narrow, width less than one half the length; off-white under straw-colored periostracum, marked with two pale, diffuse brown bands, one at mid-whorl, one on base; whorls strongly inflated; 11-13 oblique axial ribs per whorl; spiral sculpture consisting of regular shallow grooves overall; columellar callus thin; lip not thickened, labial lirae not developed. Apical whorls typically eroded, plugged.

Distribution. Monterey to San Diego, California. 70 to $600 \mathrm{~m}$. Common.

Remarks. Amphissa bicolor is easily recognized by its eroded apex, broadly spaced axial ribs, subdued spiral sculpture, and lack of lip lirae. This species is typically found in greater depths than A. reticulata and $A$. undata. This species is sometimes found in association with the bivalve Calyptogena in anoxic, reducing environments, but is also known from normal habitats (McLean 1996).

\section{Amphissa columbiana Dall, 1916}

(Figure 3A, C)

Buccinum corrugatum Reeve, 1846 [1843-1878], vol. 3, Buccinum, pl. 14, fig. 110 [non Buccinum corrugatum Brocchi, 1814].

Type. Three syntypes, NHMUK 1966608. No locality specified; Puget Sound (Oldroyd 1927); Cuming Collection.

Amphissa columbiana Dall, 1916: 27 [new name].

Amphissa columbiana altior Dall, 1921: 214, pl. 6, fig. 9 [name only in plate caption]. Type. Holotype USNM 206200. Sitka, Alaska, F. Bishoff.

Description. Shell to $30 \mathrm{~mm}$ long, width about one-half height, aperture more than one-half shell length; shell typically mottled brown with white aperture; teleoconch whorls seven, gently rounded, suture shallow, sculpture of numerous (up to 35) weak oblique axial ribs fading on anterior body whorl; spiral sculpture of regular grooves, stronger on base; columellar shield broad, sometimes projecting at shell base; columella with weak lirae anteriorly and posteriorly; lip thickened externally, with numerous low lirae internally behind labial edge. Protoconch multispiral, broadly conic, with axial sculpture.

Distribution. Unalaska, Aleutian Islands, Alaska, to Point Conception, Santa Barbara County, California. Usually intertidal in rocky/sandy areas, have been found to $25 \mathrm{~m}$ or occasionally more, especially in the northern part of the range. Common. 


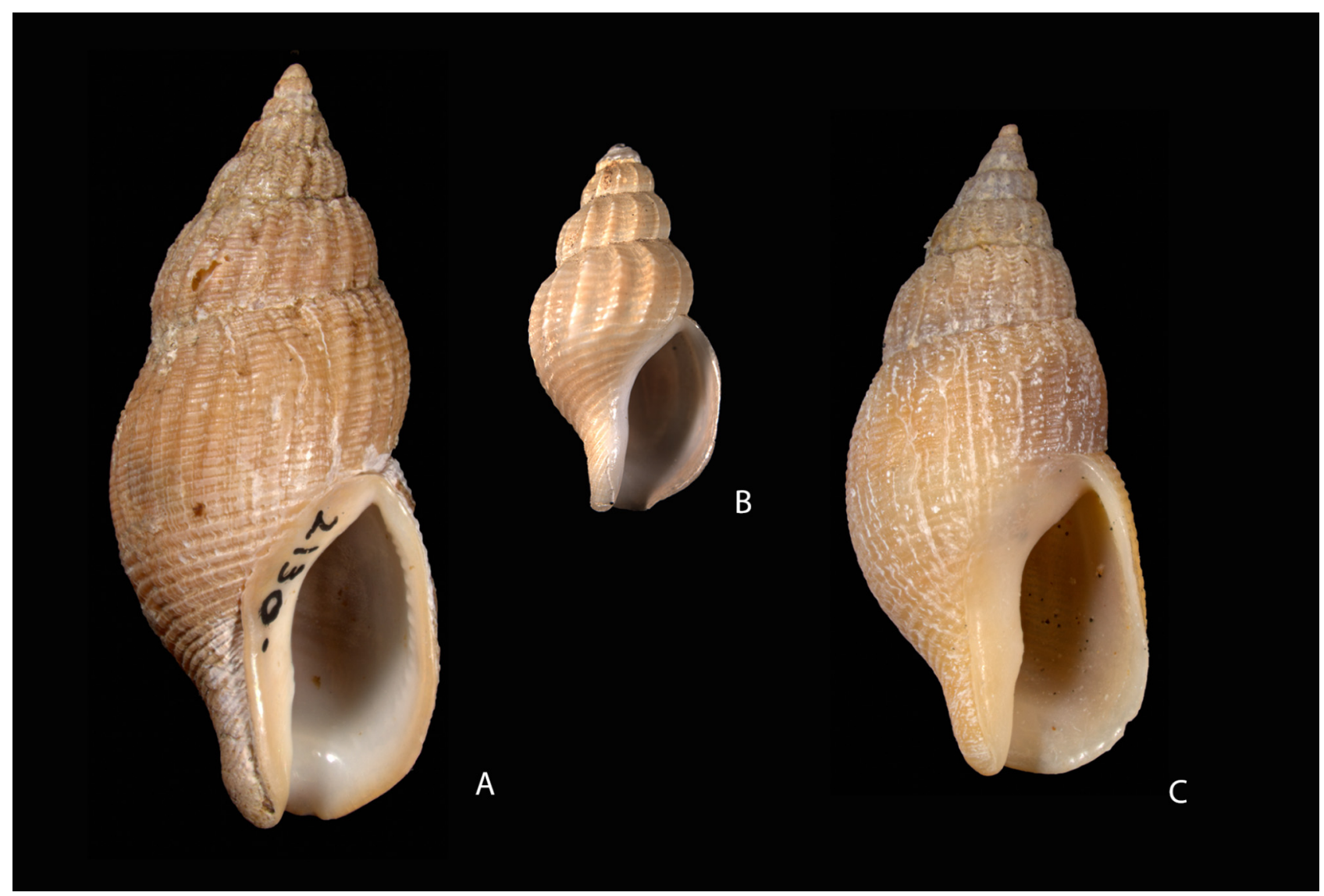

FIGURE 3. A. Amphissa columbiana Dall, 1916, Bear Bay, Sitka County, Alaska (SBMNH 102130), length 27.9 mm. B. Amphissa bicolor Dall, 1892, 238-421 m, off Santa Rosa Island, Santa Barbara County, California (LACM 1939-96.5), length 13.4 mm. C. Amphissa columbiana, dredged 30-45 m off Friday Harbor Marine Station, San Juan Islands, San Juan County, Washington (SBMNH 153385), length $23.8 \mathrm{~mm}$.

Remarks. This is the largest species of Amphissa and is most easily recognized by its finer axial sculpture and shallow sutures. The subspecies $A$. columbiana altior is a name given to a narrow specimen found in Alaska. The specimen was figured and the figure legend gives the name and reference to p. 105, but the subspecies is actually not mentioned in the text.

\section{Amphissa reticulata Dall, 1916}

(Figure 4A-C)

Amphissa versicolor var. reticulata Dall, 1916: 27. Type. Lectotype (McLean 1996: 111, fig. 1.22C) USNM 210004. RV Albatross Sta. 4332, off Point Loma, San Diego County California, 62-183 fms [113-335 m]. 16 mm long.

Description. Shell to $17 \mathrm{~mm}$ long, width slightly less than half length, aperture height about one-half length; cream colored, some with two light brown bands or one row of hazy brown blotches at periphery; whorls moderately inflated; axial ribs about 15-18 per whorl, nearly straight; spiral cords strong, overriding axial ribs, producing beads at intersections; columella with weak lirae in some; labial denticles variably well developed, projecting from aperture in some specimens. Protoconch conical with 3-3.5 whorls, velar sinus well-developed, axial sculpture.

Distribution. Kodiak Island, Alaska, to San Benito Islands, Baja California. Soft bottoms, 15-300 m. Uncommon.

Remarks. Dall (1916) differentiated this species (as a variety of $A$. versicolor) from the typical form by its "uniform whitish color, very acute spire, and fine regular corded spiral sculpture crossed by about 17 nearly straight axial narrow ribs." Typical A. versicolor has heavier, more oblique axials and a slightly 
tabulate suture. Monsecour \& Köhler (2006) also pointed to $A$. reticulata's nearly straight rather than oblique axials. It differs from $A$. undata, which is similar in size, in the much shallower suture and a greater number of lower but more uniformly developed axial ribs. Unlike $A$. columbiana and $A$. versicolor, this species occurs offshore, frequently with Astyris gausapata.

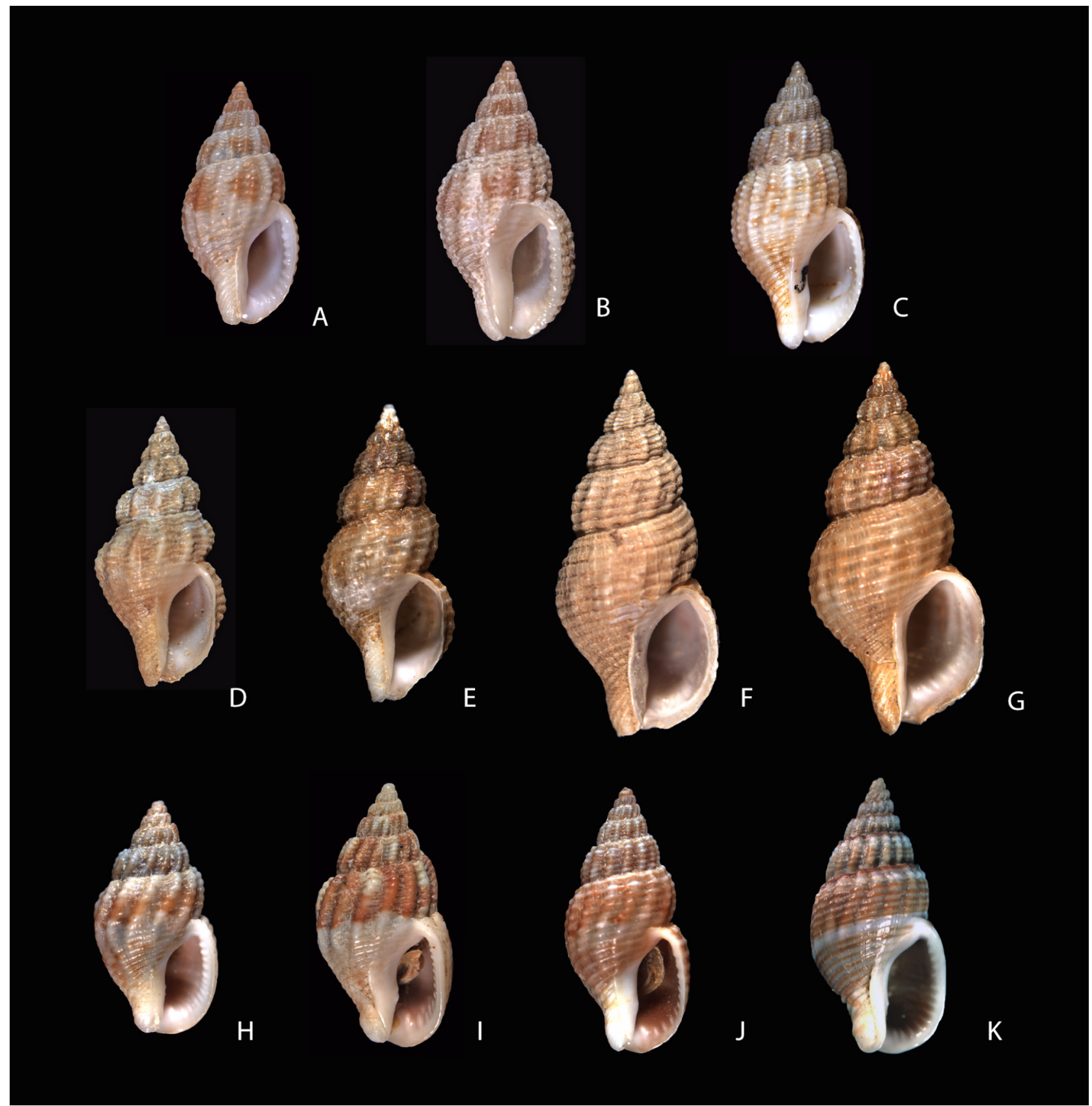

FIGURE 4. A-C. Amphissa reticulata Dall, 1916. A. 18 m, off Ramsey Island, E side Moresby Island, Queen Charlotte Islands, British Columbia (LACM 1970-93.13), 10.7 mm. B. 37-55 m, rocky bank off Point Sur, Monterey County, California (LACM 1988-356.39), 12.5 mm. C. 18-64 m, mud, Kachemak Bay, Kenai-Cook Inlet, Kenai-Cook County, Alaska (LACM 1957-11.38), 12.6 mm. D-G. Amphissa undata (Carpenter, 1864). D. 68-73 m, S side Santa Cruz Island, Santa Barbara County, California (LACM 1940-165.31), 11.9 mm. E. 40-110 m, Point Vicente, Los Angeles County, California (LACM 150651), $13.1 \mathrm{~mm}$. F. Off Point Vicente Light, Los Angeles County, California (LACM 1957-16.3), 16.4 mm. G. $40-110$ m, Point Vicente, Los Angeles County, California (LACM 150651), 16.9 mm. H-K. Amphissa versicolor Dall, 1871. H. Intertidal to 5 m, Brookings, Curry County, Oregon (LACM 1963-35.20), 10.3 mm. I. Intertidal, Franklin Point, San Mateo County, California (LACM 1962-8.36), 11.7 mm. J. Dana Point, California (LACM 150598), 11.8 mm. K. (lineata form), Dana Point, Orange County, California (LACM 172406), $12.8 \mathrm{~mm}$. 
Amycla undata Carpenter, 1864: 613 (name only), 662, not figured. Type. Holotype USNM 23284 (Palmer 1958: pl. 23, figs 1, 2). Santa Catalina Island, California, dredged $40 \mathrm{fms}[73 \mathrm{~m}]$, J. Cooper. $9.8 \mathrm{~mm}$ long.

Amphissa ventricosa Arnold, 1903: 242, pl. 5, fig. 11. Type. Holotype USNM 162550. San Pedro, Los Angeles County, California, Pleistocene.

Description. Shell to $18 \mathrm{~mm}$ long, relatively high spired, width less than half the length, aperture height less than one-half length; with well-rounded to subangulate whorls, suture deep; 11 to 15 oblique axial ribs, more pronounced at periphery, sometimes fading on body whorl; flattened spiral cords over axial ribs; shell pale tan with variegated pattern of lighter and darker brown markings under tan periostracum. Aperture with complete callus, columella smooth, labial lirae absent or weakly developed internally. Protoconch broadly conical, 3 to 3.5 whorls, with axial sculpture and a well-developed velar sinus.

Distribution. Monterey Bay, California, to Asunción Island, Baja California. Soft bottoms, 30-200 m, occasional specimens deeper. Common.

Remarks. The primary distinguishing feature of this species is the narrow, high spired shell with very deep sutures and relatively few, well-developed oblique axials, at least on early whorls; they often fade on the body whorl.

\section{Amphissa versicolor Dall, 1871}

Figure $4 \mathrm{H}-\mathrm{K}$

Amphissa versicolor Dall, 1871: 113-114, pl. 13, fig. 2 (radula), pl. 14, fig. 2, pl. 16, figs 10, 11. Type. Holotype USNM 6184. Monterey, California, Trowbridge. $12 \mathrm{~mm}$ long.

Amphissa (?versicolor var.) lineata Stearns, 1873: pl. 1, fig. 8 (illustration only). Type. Holotype USNM 12284. Monterey Harbor, California.

Amphissa versicolor var. cymata Dall, 1916: 27, not figured. Type. Syntype USNM 12295. Monterey Harbor, California.

Amphissa versicolor var. incisa Dall, 1916: 27, not figured. Type. Holotype USNM 12285. Laguna Beach, washed ashore after heavy storm, California.

Description. Shell to $16 \mathrm{~mm}$ long, sturdy, width about one-half length, with strongly impressed suture, tabulate shoulder; 13-20 strong, projecting, oblique axial ribs; interspaces of equal width; spiral cords overriding ribs, narrow on shoulder, broader on base where separated by deep incisions; columellar area with glossy shield, with two or three weak plications; lip with strong lirae, anteriormost tooth more strongly developed. Color variable; mottled gray brown or white, some with darker spiral banding or narrow spiral stripes. Protoconch conic, about three whorls, axial sculpture, with well-developed velar sinus.

Distribution. Queen Charlotte Islands, British Columbia, to Rompiente Point, northern Baja California Sur. Mostly found intertidally but may occur in deeper water, especially in the southern part of the range. Southern California and Mexican specimens are sometimes intertidal but more frequently found deeper, to 30 $\mathrm{m}$ or more. Common.

Remarks. Dall (1871) described and illustrated this species in some detail, apparently to correct Carpenter's confusion of it with the much larger A. columbiana. He then revisited the species in 1916, to differentiate four varieties (one of which was reticulata Dall), mostly by color. McLean \& Kanner (2005) speculated that var. lineata Stearns (Fig. 4K) may be a distinct species, based primarily on observations of a living specimen, in which the head and foot color differed from that of typical specimens of $A$. versicolor. The shells, other than color, are within the range of variation typically recognized in $A$. versicolor, and specimens are found rarely, together with other color variants of that species. Accordingly, lineata is a mere form of $A$. versicolor. Dall's var. cymata has wavy brown axial lines on a white shell, and var. incisa is mottled, with "sharply cut regular sculpture" (Dall 1916: 27), personal experiences with columbellid species with variable shell color and pattern indicates that the body coloration of the animal often also varies, so body coloration is insufficient to assign such a variant species status. Similarly, the sculpture also tends to vary in Amphissa species; these should be investigated with molecular phylogenetic techniques in the future to confirm the nature and degree of variation within and between species. 
Astyris H. \& A. Adams, 1853: 187. Type species (SD, Cossmann 1901: 238): Buccinum rosaceum Gould, 1840. Massachusetts.

Diagnosis. Shell thin, typically 8-13 mm long, white or off-white, biconic and moderately high-spired, whorls weakly sculptured or smooth, except for spiral grooves on base; aperture semi-lunate, typically lacking labial or parietal denticles or heavy callosities. Most with paucispiral protoconch indicative of nonpelagic development.

Remarks. Astyris species occur in cold waters at shallow to offshore depths. This genus is poorly understood and has long acted as a catchall for an array of species, usually including small, colder water biconic forms. In Radwin's (1978) revision of the western Atlantic Columbellidae, Astyris was the one genus that he could not figure out how to assess. So he simply listed 32 species that had been variously attributed to it without discussion.

The type species of Astyris, A. rosaceum (Gould), is considered circumboreal by Oldroyd (1927), who listed it as part of the northeast Pacific fauna. The type was collected off Massachusetts. The species is similar to $A$. amiantis but slightly pinkish; whether they are related or conspecific remains to be seen. The apices suggest nonpelagic development, so the likelihood of genetic continuity throughout such a large range is unlikely.

\section{Astyris amiantis Dall, 1919}

(Figure 5A-E)

Astyris amiantis Dall, 1919a: 331, not figured. Type. Holotype USNM 221008 (Kaicher 1984: card 3852(2)). Beach, Kiska Harbor, Rat Island, Aleutian Islands, Alaska, W.H. Dall. $13 \mathrm{~mm}$ long.

Description. Shell typically 9-13 mm long, with 5-6 teleoconch whorls, width to length ratio $0.40-0.45$, aperture height about one-half shell length; shell white or off-white, moderately broad, early whorls weakly rounded, changing to strongly rounded in penultimate, final whorl; some with axial sculpture of low, irregular ribs, usually stronger on posterior half of whorl; spiral sculpture, also variably present, of fine incised grooves. Some without sculpture except for spiral grooves at base. Periostracum thin, straw colored. Protoconch smooth, conical to bulbous, white, 1.75-2.25 whorls, no velar sinus but varicose at the protoconch/ teleoconch transition.

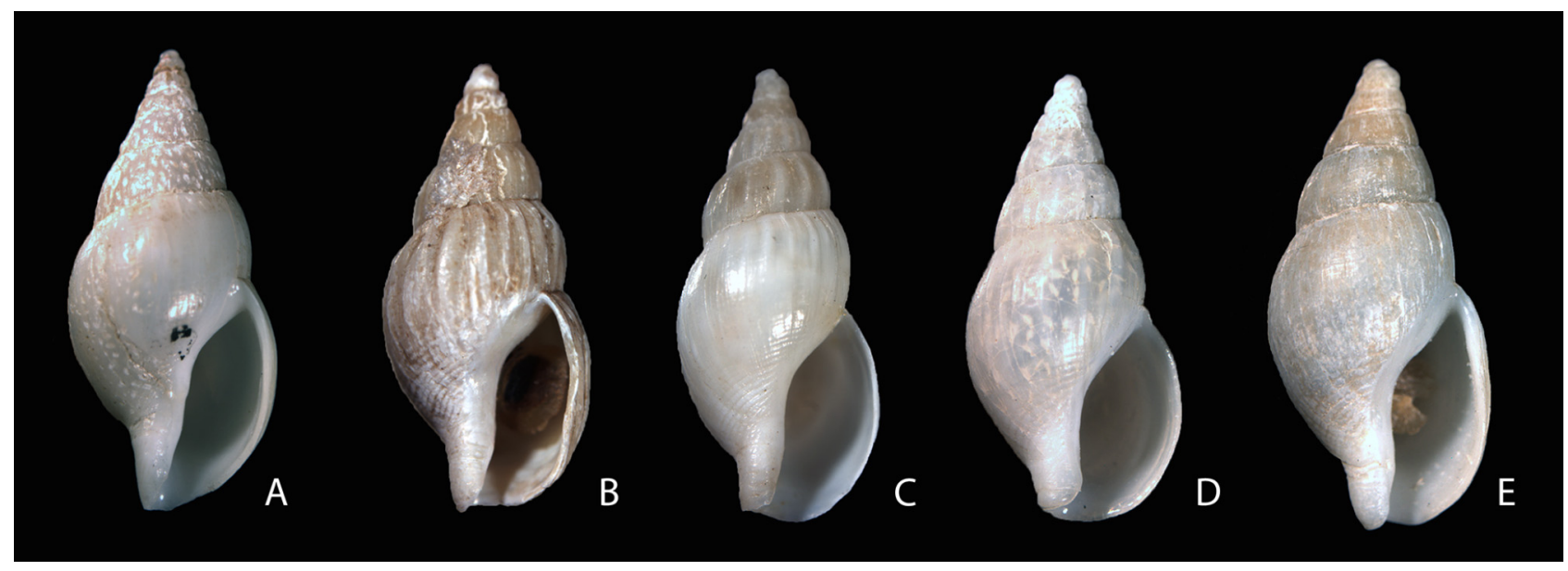

FIGURE 5. Astyris amiantis Dall, 1919. A. Intertidal, Seldovia Pt., northern Kenai Peninsula, Kachemak Bay, Kenai-Cook County, Alaska (LACM 1958-11.41), 11.8 mm. B. Intertidal, St. Makarius Bay, Amchitka Island, Aleutian Islands, Alaska (LACM 1969-43.3), 8.7 mm. C. Intertidal, Gibson Island, N side of Attu Islands, Near Islands, Alaska (LACM 1979-74.5), 10.0 mm. D. Intertidal, Gibson Island, N side of Attu Islands, Near Islands, Alaska (LACM 1979-74.7), 9.8 mm. E. Intertidal, Massacre Bay, Pacific side of Attu Island, Near Islands, Alaska (LACM 1979-66.18), 9.7 mm. 
Distribution. Aleutian Islands to Kachemak Bay, Alaska, intertidal to over $40 \mathrm{~m}$. Common in Aleutian Islands, uncommon in Gulf of Alaska.

Remarks. This species is variable in profile but has a broader body whorl than other species, and tends to be solid whereas some other regional congeners are thin-shelled and slightly translucent. The holotype is an unusually large, broad specimen with a small aperture, but it falls within the variation of the species. It is similar to $A$. rosacea although larger.

\section{Astyris elegans Gulbin, 1983}

(Figure 6A, B)

Astyris elegans Gulbin, 1983: 1576, text figs b, d, e. Type. Holotype, IMBV 1/42672. Off Bering Island, Commander Islands, $40 \mathrm{~m} .11 .2 \mathrm{~mm}$ long.

Description. Shell to $12 \mathrm{~mm}$ long, width to length ratio $0.33-0.37$; translucent white or off-white; with 4-6 moderately rounded teleoconch whorls; regular fine spiral grooves more or less pronounced overall, some specimens essentially smooth. Aperture neither thickened nor denticulate. Protoconch white, peglike or broadly conical, unsculptured, 2-2.25 whorls, without a velar sinus.

Distribution. Aleutian Islands, Alaska, to Vancouver, British Columbia, intertidal to $165 \mathrm{~m}$, common, most common around $100 \mathrm{~m}$.

Remarks. This species is narrower than A. amiantis, and less sculptured than A. lattis.

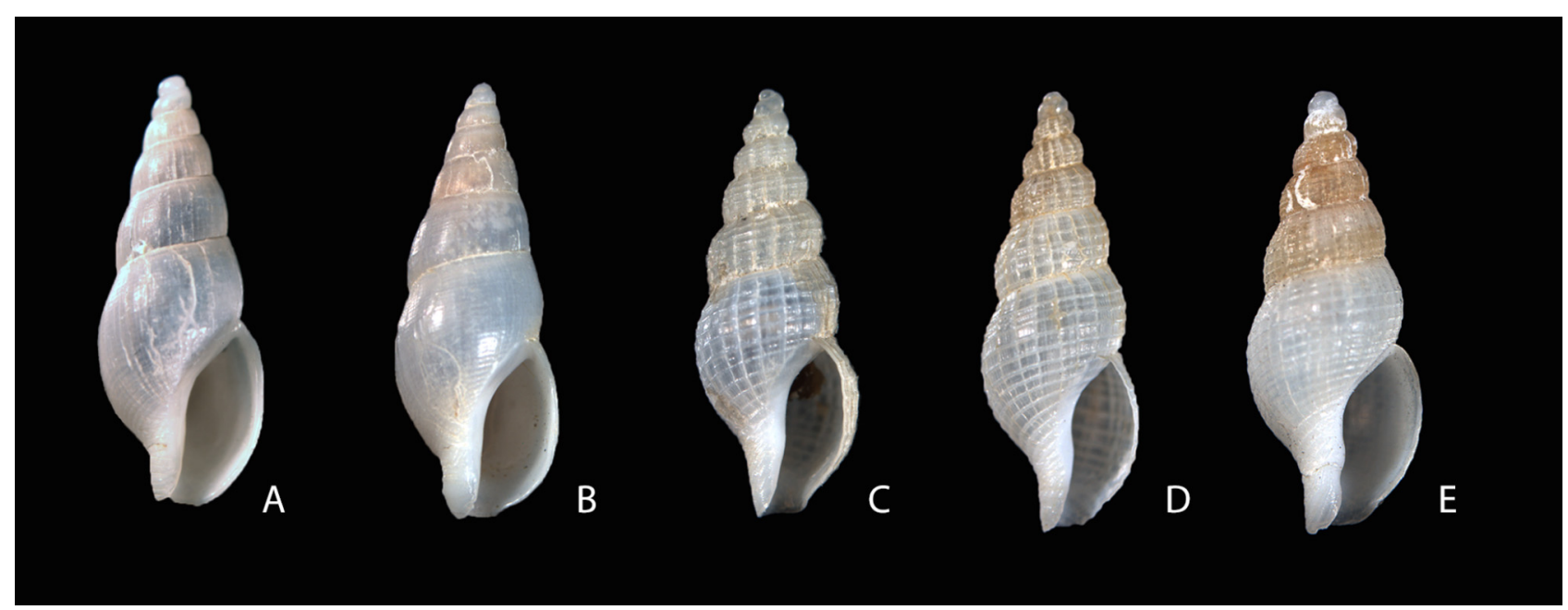

FIGURE 6. A-B. Astyris elegans Gulbin, 1983. A. Offshore, NE of Kiska Island, Rat Islands, Aleutian Islands, Alaska (LACM 1997-159.1), 7.2 mm. B. Intertidal, S side of Eider Point, Unalaska Bay, Alaska, (LACM station 1993-71), 10.0 mm. C-E. Astyris lattis n. sp. C. 103 m, Sitkin Strait, Adak Island, Andreanof Islands, Aleutian Islands, Alaska (LACM 3614, holotype), $8.3 \mathrm{~mm}$. D. $121 \mathrm{~m}$, N of Carlisle Island, Islands of Four Mountains, Aleutian Islands, Alaska (LACM 3615, paratype, LACM 1986-333.6), $8.3 \mathrm{~mm}$. E. $152 \mathrm{~m}, \mathrm{~S}$ of Semichi Island, Near Islands, Aleutian Islands, Alaska (paratype, LACM 3616, LACM 1986-356.3), $7.2 \mathrm{~mm}$.

Astyris lattis n. sp.

(Figure 6C-E)

Type material. Holotype: LACM 3614 (LACM 1997-186.2), 103 m, Sitkin Strait, Adak Island, Andreanof Islands, Aleutian Islands, Alaska (51 ${ }^{\circ} 54.8^{\prime} \mathrm{N}, 176^{\circ}$ 50.6' W), R.N. Clark, RV Dominator (sta. 23-971-SH-7), 23 July 1997; 8.3 mm long. Paratypes: 2 spm, LACM 3615 (LACM 1986-333.6), $121 \mathrm{~m}, \mathrm{~N}$ of Carlisle Island, Islands of Four Mountains, Aleutian Islands, Alaska (52 58.53' N, 170 02.60' W), R. Baxter (sta. 86-251), 18 September 1986. 1 spm., LACM 3616 (LACM 1986-356.3), 152 m, S of Semichi Island, E of Cape Sabak, Agattu Island, Aleutian Islands, Alaska (52 $22.74^{\prime}$ N, 174 7.26' E), R. Baxter (sta. 86-292), 23 August 1986.

Etymology. Named for the lattice-like sculpture, following McLean ms. Noun in apposition.

Description. Shell 7-9 mm long, slender, length to width ratio $0.33-0.37$; with $4.5-5$ teleoconch whorls; 
translucent white, some with straw-colored early whorls; suture moderately impressed; axial sculpture of narrow raised costae, over spiral sculpture of narrow, widely separated raised cords, forming grid-like sculpture. Aperture without thickening or denticles. Protoconch white, broadly conical, unsculptured, 2.25 whorls, no velar sinus.

Distribution. Only four specimens found; Aleutian Islands, Alaska, in depths of 103 to $152 \mathrm{~m}$.

Remarks. This is similar to A. costata Gulbin, 1983, which has denser spiral ridges, much weaker axials and a somewhat recurved siphonal canal.

\section{Astyris permodesta (Dall, 1890)}

(Figure 7A-B)

Columbella (Astyris) permodesta Dall, 1890: 327-328, pl. 5, fig. 4. Type. Lectotype (designated by McLean 1996: 110, fig. 1.22B) USNM 96526. RV Albatross sta. 2840, off the Santa Barbara Islands, California, $276 \mathrm{fms}$ [505 m]. $11.6 \mathrm{~mm}$ long.

Description. Shell to $14 \mathrm{~mm}$ long, broadly inflated, thin, off-white under greenish brown periostracum, but often coated with dark brown mineral deposits; apex decollate and plugged, leaving just 3-3.5 whorls; sculpture lacking except for weak spiral cords on base of shell. Lip thin, lacking lirae; columella simple, siphonal canal wide open.

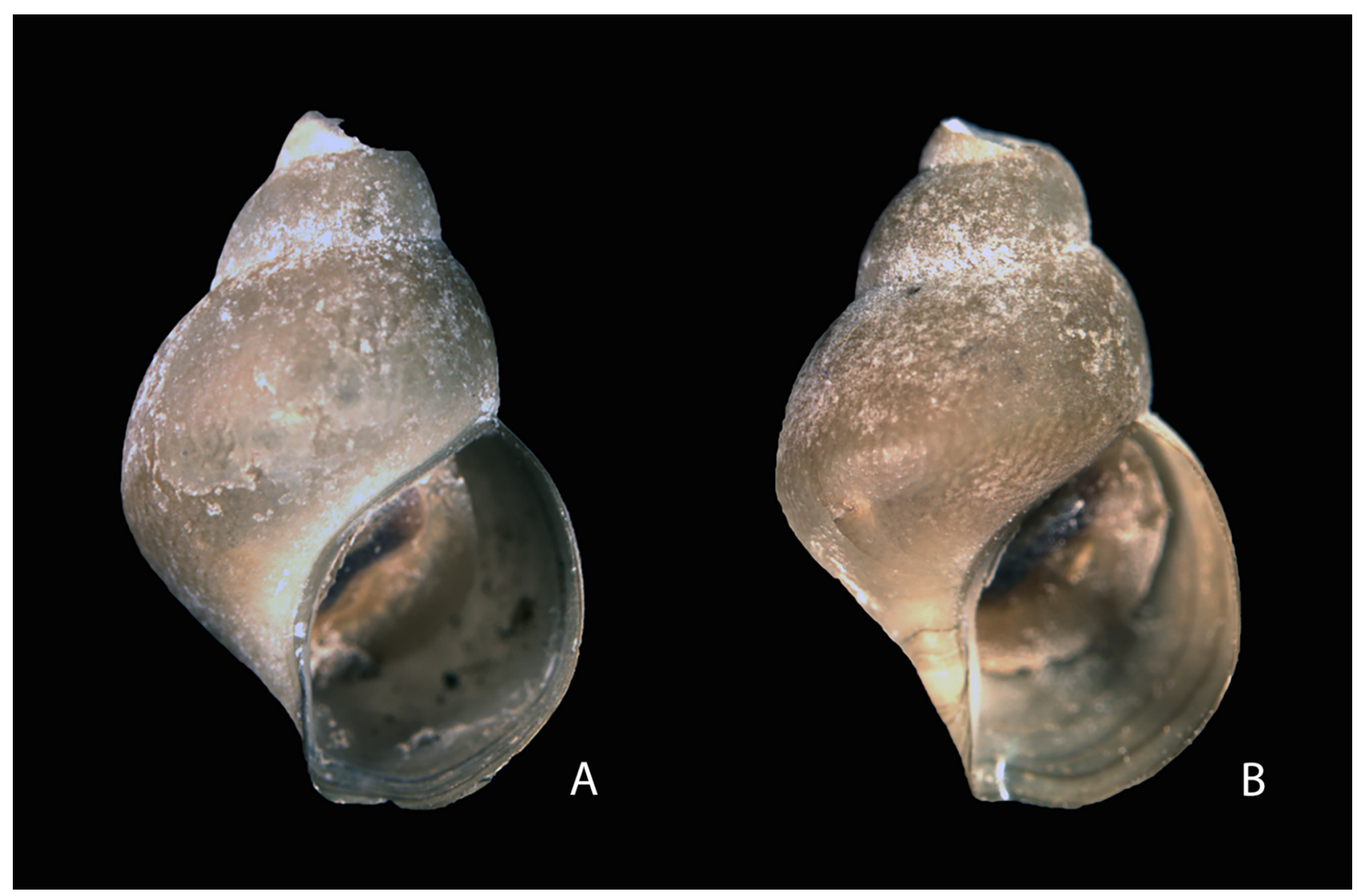

FIGURE 7. Astyris permodesta (Dall, 1890). A-B. 586 m, Oregon Margin Seep, off Eureka, Humboldt County, California, 40 41.16' N, $125^{\circ}$ 5.83' W (LACM station 1999-46). A. $8.1 \mathrm{~mm}$. B. $8.3 \mathrm{~mm}$.

Distribution. Cape Foulweather, Lincoln County, Oregon, to San Diego, San Diego County, California. Soft bottoms with cold seeps, whale carcasses, and anoxic greenish gray mud, 500-1900 m. Common.

Remarks. The species is characteristic of anoxic bottoms of offshore basins. Several of the recorded localities include cold seeps, and it is also a common inhabitant of whale bone in deep water (Smith et al. 1989), where it occurs along with species of large vesicomyid bivalves and other characteristic inhabitants of reducing environments. 
The generic assignment is based on the thin lip without lirae; it may prove to be unrelated. It differs from Mitrella gausapata in lacking the lirae and in having a thinner and broader shell. A very similar species (Astyris atacamensis Araya, Catalán \& Aliaga, 2016) has recently been named from anoxic deep water habitats off Chile.

\section{Exaesopus new gen.}

Type species. Anachis subturritus Carpenter, 1864. Northeast Pacific.

Included species. Type species and Aesopus osborni Hertlein \& Strong, 1951, from southern Mexico, which is smaller and more slender.

Etymology. Named as a taxon that has been removed from Aesopus. Gender masculine.

Diagnosis. Shell small, 3-5 mm long with about four teleoconch whorls. Shell narrow with moderately incised sutures, with the primary sculpture consisting of pronounced axial ridges overall. Aperture semilunate, with no denticles or notable thickening of the labial edge.

Remarks. The type species has been variously and inconsistently assigned to a genus by previous authors. It was retained by Palmer (1958) in Anachis. Keen (1971: 576) placed the type species in Aesopus Gould, 1860, subgenus Ithiaesopus Olsson \& Harbison, 1953, from which Exaesopus subturritus differs in having a shorter aperture, a more impressed suture and much fewer, broader and stronger axial ribs than the thin lamellar axials of Ithiaesopus. An affinity between Aesopus, in which there is fine spiral sculpture only, and Ithiaesopus in which there is fine axial sculpture, is evident, based on shell shape, but Exaesopus, with its lack of a descending suture, deeper suture and strong axial sculpture, is not morphologically similar to either genus.

\section{Exaesopus subturritus (Carpenter, 1864)}

(Figure 8A-D)

Anachis subturritus Carpenter, 1864: 613, 664; 1866: 223, not figured. Type. Holotype USNM 14952 (Palmer 1958: pl. 23, figs

7, 8). San Diego, California, J.G. Cooper. $4.5 \mathrm{~mm}$ long.

Anachis petravis Dall, 1908: 250, not figured. Type. Holotype USNM 110645. Bird Rock, San Diego, California, Kelsey.

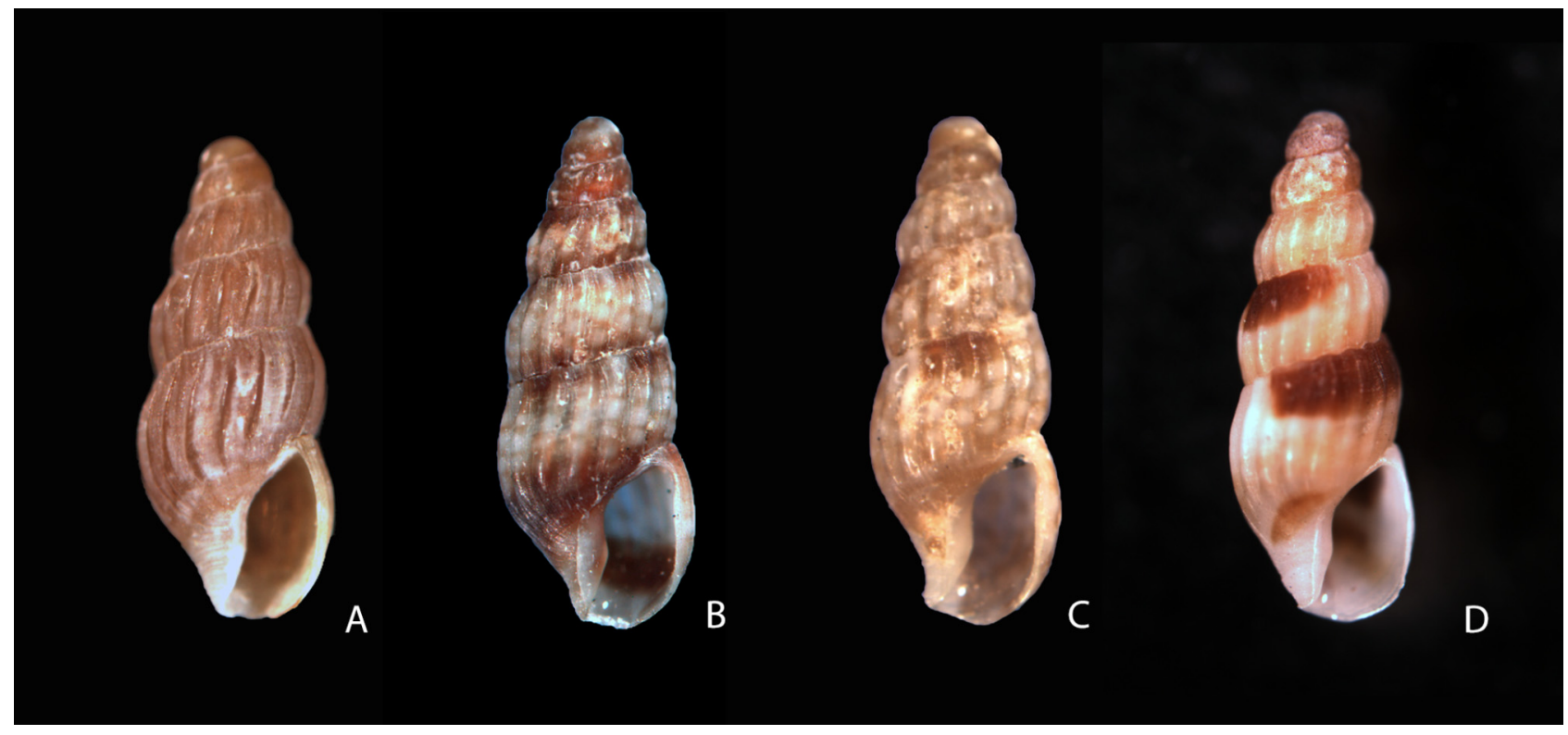

FIGURE 8. Exaesopus subturritus (Carpenter, 1864). A. 50-120 ft. [15-37 m], S side Guadalupe Island, Baja California (LACM 1965-42.33), 3.0 mm. B. 14 m, NW end Cedros Island, Baja California (LACM 1972-114.34), 4.2 mm. C. 14 m, NW end Cedros Island, Baja California (LACM 1972-114.34), 3.6 mm. D. 40-90 ft. [12-27 m], SW side Guadalupe Island (Afuera Island), Baja California (LACM 1972-120.32), $4.04 \mathrm{~mm}$. 
Description. Shell 3-5 mm long, high-spired with 4-4.5 convex teleoconch whorls; sculpture of regular oblique axials overall, with fine spiral scratches between. Width to length ratio $0.35-0.4$. Color off-white to brown, usually with white dots or pattern of spiral streaking in mesh-like pattern, darker near sutures. Base, aperture edge white in many. Some specimens with solid dark purple-brown blotches below suture. Protoconch 1.75-2 whorls, peg-like, usually tan or brown with some white, lacking sculpture, no velar sinus.

Remarks. Carpenter gave this species minimal treatment in 1864 (name only on p. 613 and a one-line description on p. 664), then described it more completely in 1866 . Some authorities thus cited the date erroneously as 1866 .

Distribution. Santa Catalina Island, California, to Tres Marias Islands, Mexico, and possibly further south. Occasionally intertidal but more common from depths of 3-40 m.

\section{Genus Ithiaesopus Olsson \& Harbison, 1953}

Ithiaesopus Olsson \& Harbison, 1953: 241. Type species (OD): Anachis ithitoma Dall, 1890. Pliocene of Florida.

Diagnosis. Shell narrow, high spired, with short aperture, shallow sutures.

Remarks. These are similar to Aesopus in the pupoid profile, but with usually irregular fine axial riblets. They typically lack the dropped suture on the body whorl.

\section{Ithiaesopus arestus (Dall, 1919)}

(Figure 9A-E)

Aesopus arestus Dall, 1919a: 332, not figured. Type. Holotype USNM 217928 (Kaicher 1985: card 4283). Magdalena Bay, Baja California, C.R. Orcutt. $7 \mathrm{~mm}$ long.

Description. Shell 6-8 mm long, with 4.5-5.5 teleoconch whorls. Shell glossy, high-spired, with large body whorl, suture minimally impressed. Aperture edge thin, not denticulate, usually projecting anteriorly past tip of columella. Sculpture of weak thin axials on early whorls (Fig. 9E), fine spiral scratches overall. Off white with white, chestnut to dark brown markings, or purple brown, often with reticulate pattern of white dots; color, pattern variable. Colored shells often with one spiral chain of white dots below suture. Protoconch blunt, conical, smooth, white or tan, about 1.75 whorls, with no velar sinus.

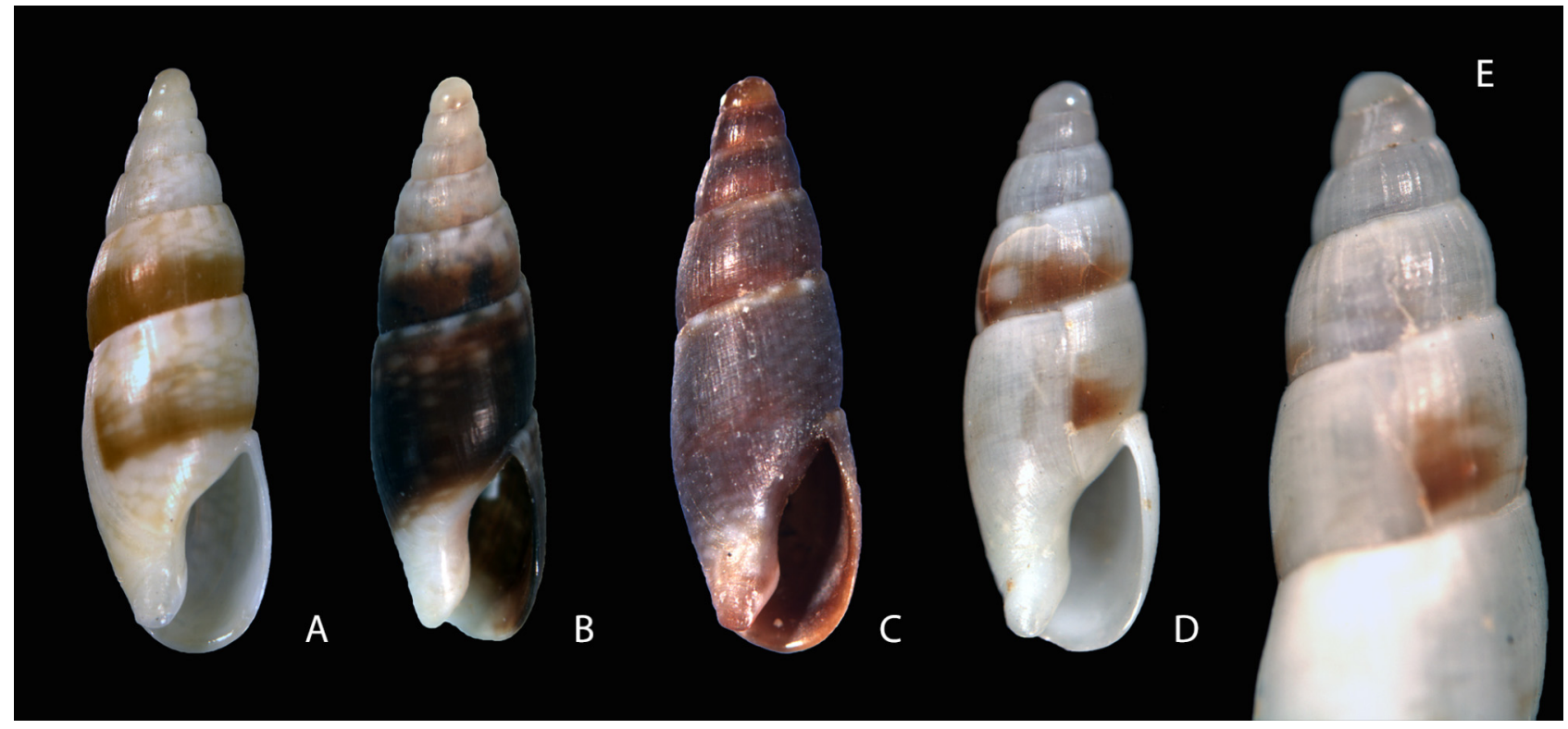

FIGURE 9. Ithiaesopus arestus (Dall, 1919). A. 20-50 m, rocky, rocks \& pinnacles of Rocas Alijos (LACM 1990-119.16), 8.2 mm B. 20-50 m, rocky, rocks \& pinnacles of Rocas Alijos (LACM 1990-119.16), 7.5 mm C. 30-70 ft. [9-21 m], NW side of Guadalupe Island, Baja California (LACM 1972-121.26), 6.8 mm. D, E. 40-90 ft. [12-27 m], SW side of Guadalupe Island, Baja California (LACM 1972-120.33), $6.7 \mathrm{~mm}$. E. Detail of spire showing axial ridges. 
Distribution. Outer Baja California and the offshore islands (Guadalupe Island, Natividad Island, Rocas Alijos), 10-30 m. Locally common.

Remarks. Ithiaesopus arestus is typically a white or mostly white shell, so this species may prove to be something different, but there is nothing substantive to differentiate them at present.

\section{Genus Mitrella Risso, 1826}

Mitrella Risso, 1826: 247-248. Type species (SD: Mörch, 1859) Mitrella scripta Linnaeus, 1758. Mediterranean.

Diagnosis. "Shell 4-20 mm long, biconic; spire high, acute, suture shallow; body whorl equal to or shorter than spire, aperture moderately broad, apertural lip denticulate, siphonal canal very short to moderately long, columella straight, parietal callus denticulate in some; shell surface smooth" (Radwin 1978: 337).

Remarks. Mitrella is a rather heterogeneous collection of a large number of species from all over the globe, united primarily by the simple elongate biconic shape of the shell and lack of shell sculpture. Accordingly, the genus is likely, upon further revision, to be split into many unrelated groups. Relative to the species here, most species placed in Mitrella have relatively straight-sided shells, with well-developed labial denticles and more often than not a conical multiwhorled protoconch indicative of a planktonic larval stage. Ironically, the type species is a large species from the eastern Atlantic and Mediterranean with a paucispiral protoconch. It is not unusual in columbellids for related species to have different modes of larval development (this occurs for instance in Columbella).

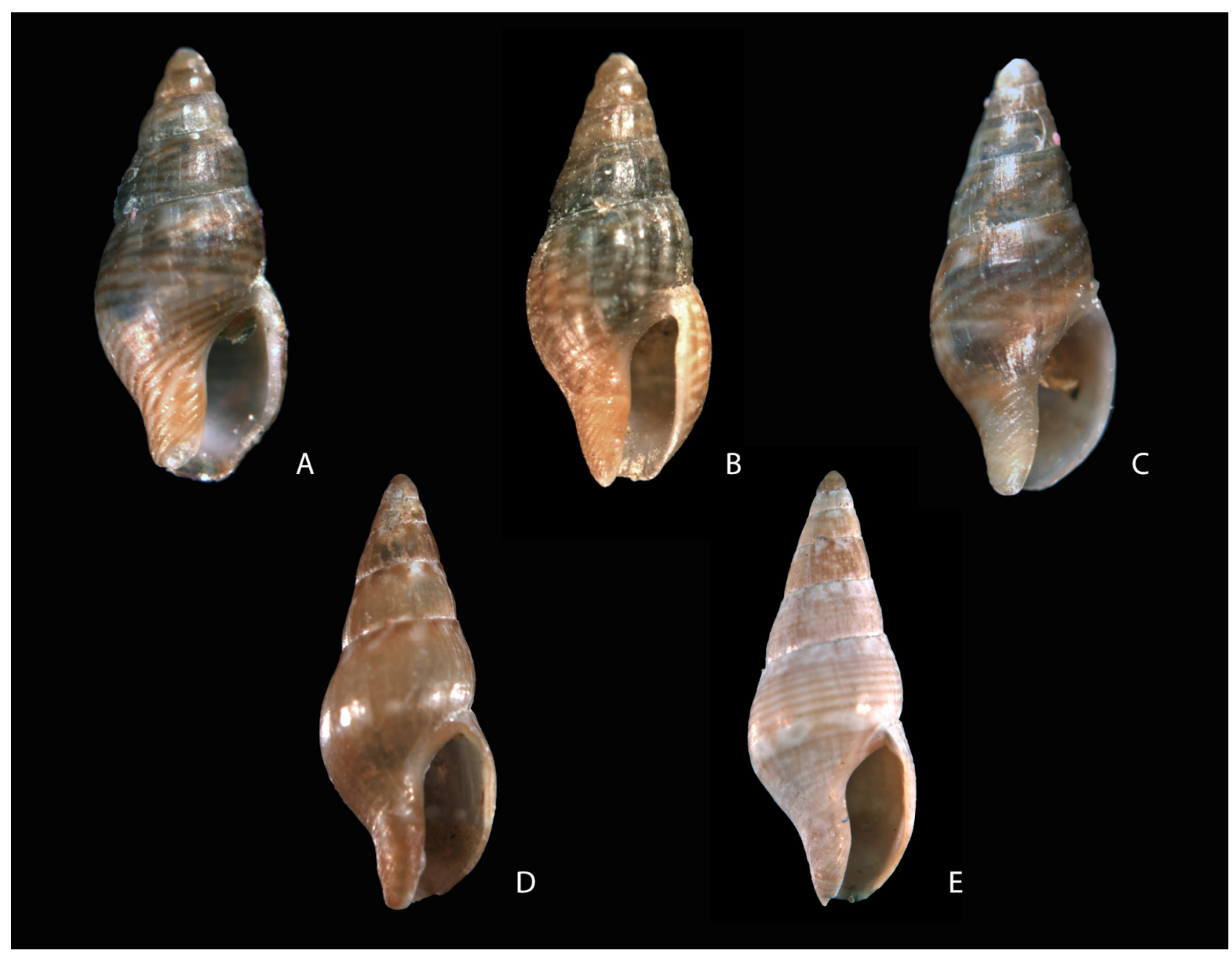

FIGURE 10. A-C. Mitrella aurantiaca (Dall, 1871). A. 15-26 m, S side of Anacapa Island, California, (LACM 1964-28.34), 4.3 mm. B. 15-26 m, S side of Anacapa Island, California, (LACM 1964-28.34) 4.3 mm. C. San Luis Obispo, San Luis Obispo County, California (LACM 52909), 4.5 mm. D-E. Mitrella variegata (Stearns, 1873), 5-12 m, NE end Cedros Island, Baja California (LACM 1971-151.52). D. 5.9 mm. E. $6.3 \mathrm{~mm}$. 


\section{Mitrella aurantiaca (Dall, 1871)}

(Figure $10 \mathrm{~A}-\mathrm{C}$ )

Astyris aurantiaca Dall, 1871: 115-116, pl. 15, fig. 13. Type. Holotype USNM 12313. Monterey Harbor, California, W.H. Dall. $4.6 \mathrm{~mm}$ long.

Description. Shell 3-5 mm, with about four teleoconch whorls; biconic, suture shallow; semi- translucent, usually smooth except for spiral striations on canal, but some specimens with broad, low axials, mostly on body whorl. With chevron pattern of thin, brown lines on off-white background (not irregular pattern of wavy longitudinal lines), usually with spiral row of white blocks below suture; labial edge not denticulate; columella smooth, without much callus; protoconch broadly conical, brown with paler flush, 1.75-2 whorls, no velar sinus.

Distribution. Vancouver Island, British Columbia, to Cedros Island, Baja California. Intertidal to $20 \mathrm{~m}$; uncommon but most often found in low intertidal zone among rocks and algae.

Remarks. Axial ridges are rare in species of Mitrella, but are also present in M. baccata Gaskoin, 1852, from Mexico to Central America and M. caulerpae Keen, 1971, from Baja California. This species was described in Astyris, but those tend to be cold-water taxa with thin, white shells.

\section{Mitrella gausapata (Gould, 1850)}

(Figure $11 \mathrm{~A}-\mathrm{C}$ )

Columbella gausapata Gould, 1850: 170, not figured; 1852: 267; 1856: pl. 19, fig. 337. 'Probable figured holotype' USNM 5732 (Johnson 1964: 82). McLean (1996: 109) incorrectly referred to this as a lectotype designation. Puget Sound, Washington. $13 \mathrm{~mm}$ long.

Columbella (Nitidella?) dalli E.A. Smith, 1880: 287, not figured. Type. Five possible syntypes NHMUK 1868.2.17.33, 1880.6.23.11-12, all are slightly smaller than the cited type measurement. Vancouver Island.

?Nitidella lutulenta Dall, 1919a: 331, not figured. Type. Holotype USNM 211068. RV Albatross station 3180, San Francisco, $44 \mathrm{~m}$.

Alia casciana Dall, 1919a: 330, not figured. Type. Holotype USNM 209456. RV Albatross station 4322, Point La Jolla, San Diego.

Description. Shell 8-13 mm long, thick, with up to six teleoconch whorls; smooth except for microscopic spiral striations; base with spiral grooves; apex usually deeply eroded in mature specimens; lip with weak lirae away from edge; periostracum adherent, brown; shell straw colored, with white chevron or mottled markings. Uneroded apex in one specimen suggesting conical protoconch, with about three whorls.

Distribution. Bechevin Bay, NW side Alaska Peninsula, Alaska, to San Pablo Point, Baja California Sur. Soft bottoms, 30-200 m. Common.

Remarks. Historically this species was incorrectly considered a synonym of the shallow-water species Alia carinata. It was misidentified as Mitrella gouldii Carpenter (a synonym of Alia carinata) by Grant \& Gale (1931: 695) and Abbott (1974: 198). Dall's species lutulenta and casciana, which have been ignored in the literature, were placed in the synonymy of this species by McLean (1996). It is placed in Mitrella here because of the thick, colored shell, and it bears some resemblance to the northwest Pacific species M. bicincta (Gould, 1860) and M. burchardti (Dunker, 1877).

\section{Mitrella variegata (Stearns, 1873)}

(Figure $10 \mathrm{D}, \mathrm{E})$

Astyris variegata Stearns, 1873: 81, pl. 1, fig. 5 [non Columbella variegata Menke, 1828]. Type. Holotype USNM 12297. San

Diego, California, Stearns Collection, ex H. Hemphill. $7 \mathrm{~mm}$ long.

Columbella (Astyris) hypodra Dall, 1916: 27 [new name].

Description. Shell about $7 \mathrm{~mm}$ long, with about five teleoconch whorls; body whorl wide relative to previous whorls, sutures shallow; labial edge sinuous, usually not denticulate, some with weak internal lirae in the aperture; columella smooth, callus lacking. Color tan, with white spots or lines. Protoconch broadly conical, tan, about two whorls, no velar sinus. 
Distribution. San Diego, California, to Cedros Island, Baja California. Subtidal to $12 \mathrm{~m}$. Rare.

Remarks. Though Stearns named this species as a member of Astyris, Dall (1916) referred to it as Columbella (Astyris) variegata and declared it preoccupied by $C$. variegata Menke, 1828, so renamed it. The current placement of variegata in Mitrella removes the secondary homonymy and the Stearns' name is reinstated in accordance with ICZN Art. 59.4. Stearns (1873) noted that this species differs from M. tuberosa in the greater convexity of the whorls and the lack of a basal angularity, as well as having fewer protoconch whorls. It differs from M. aurantiaca in lacking axial ridges, and the markings are spiral rather than zig-zag.

\section{Mitrella tuberosa (Carpenter, 1864)}

(Figure $11 \mathrm{D}-\mathrm{F}$ )

Amycla tuberosa Carpenter, 1864: 537, 539, 628, 662 (brief description); complete description 1865: 398. Type. Five syntypes, RM No. 73 (Palmer 1958: pl. 26, figs. 9-12). Santa Barbara, California, Pleistocene.

Columbella tuberosa major Oldroyd, 1925: 24, pl. 2, fig. 11. (as Alia tuberosa major). Type. Holotype USNM 352369. Lower Pleistocene of Nob Hill cut, San Pedro, Los Angeles County, California.

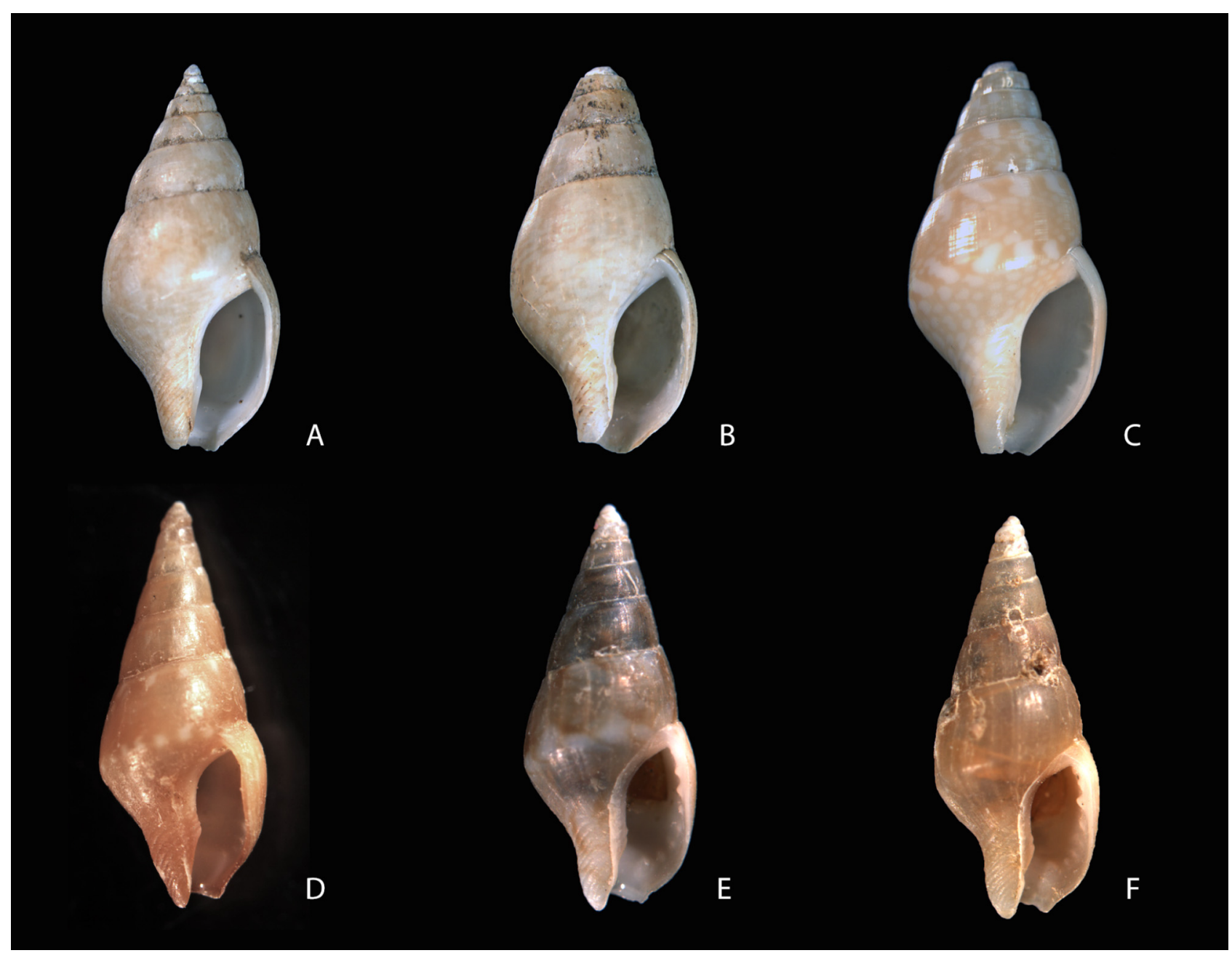

FIGURE 11. A-C. Mitrella gausapata (Gould, 1850). A. 10-30 fms [18-55 m], Forrester Island, Prince of Wales County, Alaska (LACM 161254), 12.9 mm. B. 6 m, mud \& sand, S of Stockton Island, North Slope County, Alaska (LACM 1988337.3), $9.8 \mathrm{~mm}$. C. $15 \mathrm{fms}$ [27 m], on algae, Marrowstone Island, Jefferson County, Washington (LACM 173014), $12.2 \mathrm{~mm}$. D-F. Mitrella tuberosa (Carpenter, 1864). D. 18 m, Hotspring Island, British Columbia (LACM 1970-92.11), 7.4 mm. E-F. 12-38 m, rock \& kelp, Carmel Submarine Canyon, N end San Jose Creek Beach, Monterey County, California (LACM 196024.86), E. $6.0 \mathrm{~mm}$. F. $6.6 \mathrm{~mm}$. 
Description. Shell 6-8 mm long, with about five teleoconch whorls; spire tall, sutures barely impressed, body whorl strongly angulate at mid-whorl; labial edge denticulate within, columella with thin callus, two or three small ridges on angulation. Periostracum of living specimens forms axial ridges. Color tan, some specimens showing fine white mottling, some darker colored. Protoconch off-white to tan, 3-3.25 whorls, moderately developed velar sinus, last protoconch whorl wider than first teleoconch whorl.

Description. Montague Island, Prince William Sound, Alaska, to San Pablo Point, Baja California. Intertidal in sand and gravel and in beach drift; more common subtidally, in gravel and under kelp.

Remarks. The shell is similar to that of $M$. variegata, but the protoconch is much larger, and the teleoconch whorls flatter, with a basal angulation. Pleistocene specimens described as A. tuberosa major reach a larger size $(11 \mathrm{~mm})$, compared to about $8 \mathrm{~mm}$ for living specimens.

\section{Genus Zanassarina Pilsbry \& Lowe, 1932}

Zanassarina Pilsbry \& Lowe, 1932: 75. Type species (OD): Nassarina (Zanassarina) poecila Pilsbry \& Lowe, 1932. San Juan del Sur, Nicaragua.

Diagnosis. "Shell similar to Nassarina except that the embryonic shell is conic, of 2.5-3 smooth, convex whorls, the initial whorl small. No distinctly contracted anterior canal. Lip with a distinct anal sinus. Sculpture of coarse axial ribs overridden by spiral cords. The operculum is unguiculate [like a toenail?] with apical (basal) nucleus" (Pilsbry \& Lowe 1932: 75).

Remarks. Zanassarina was originally described as a subgenus of Nassarina Dall, 1889, and is also similar to Cigclirina Woodring, 1928. Species in these genera are generally small, 4-8 $\mathrm{mm}$ long, high spired, with moderately rounded whorls, simple adentate apertures and a combination of spiral ridges and welldeveloped axial ribs. Zanassarina in particular was distinguished for its multiwhorled protoconch (not in itself an informative character in columbellids as protoconch type varies within otherwise well-delimited genera) and less constricted aperture than in Nassarina. The species listed here also share a lack of labial or columellar denticles, which are typically present in most columbellids, including species of Nassarina and Cigclirina. There are a number of species in these and similar genera, which given their fairly general characteristics, will likely require molecular research to sort out.

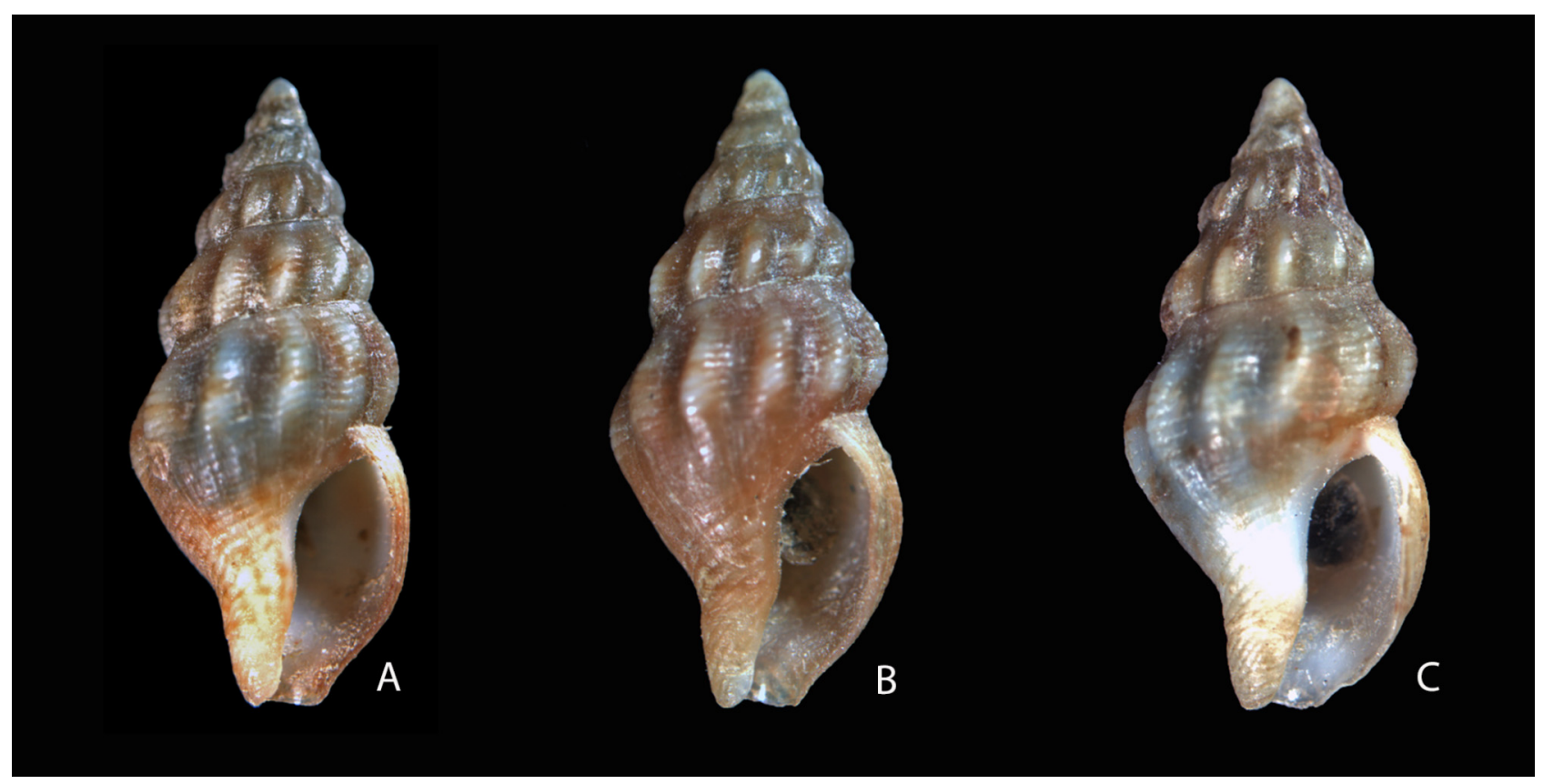

FIGURE 12. A-C. Zanassarina conspicua (C.B. Adams, 1852), $5 \mathrm{~m}$ in mud, off Cabo Tortola, Turtle Bay, Baja California (LACM 1949-53.16). B. 8.0 mm. C. 6.7 mm. D. $7.1 \mathrm{~mm}$. 
Columbella conspicua C.B. Adams, 1852: 83-84, not figured. Type. Holotype MCZ 186390 (Turner 1956: pl. 7 fig. 3 ). Panama, $5.3 \mathrm{~mm}$ long.

Description. Shell 5-8 mm long, with about 5.5 teleoconch whorls. Shell thick, chunky with oblique axials bulging at periphery but fading above, below; fine spiral grooves overall. Apex eroded in all specimens. Color, pattern varied; white with generally spiral brown markings to red brown with white areas atop axials. Aperture edge not denticulate, only slightly thickened.

Distribution. Cedros Island, Baja California, and points south; Panama. Intertidal to about $30 \mathrm{~m}$. Uncommon.

Remarks. Identification of this species is tentative; it is previously known only from the Panamanian holotype, which is a bit small. The placement of this species follows Skoglund (1992).

\section{Zanassarina guadalupensis $\mathrm{n}$. $\mathrm{sp}$.}

(Figure 13A-C)

Type material. Holotype: LACM 3617 (LACM station 1965-42), 15-37 m, Guadalupe Island, Baja California, Mexico (28? 53.5' N, 118? 16' W), L. Thomas, B. Owen, October 1965; 4.3 mm (Fig. 13A). Paratypes: 82 additional spms from the type locality (LACM 3618, LACM station 1965-42); 3 spms, LACM 3619 (LACM station 1933-143), 25 fms [46 m], Melpomene Cove, S end of Guadalupe Island, Baja California; 3 spms, LACM 3620 (LACM station 1957-2), 17-23 fms [31-42 m], Guadalupe Island, Melpomene Cove, E of Zapato Islet, C.L. Hubbs, 18 December 1957; 18 December 1957; 21 spms, LACM 3621 (LACM station 1972-120), 40-90 ft. [12-27 m], Afeura Island, Adentro, 5 Fathom Bank \& basalt arches, SW side Guadalupe Island, J.H. McLean, 27 September 1972; 50 spms from LACM 3622 (LACM station 1972-121), 9-21 m, NW side of Guadalupe Island, Baja California (29¹1.3' N, $\left.118^{\circ} 15.2^{\prime} \mathrm{W}\right)$, J.H. McLean, 28 September 1972.

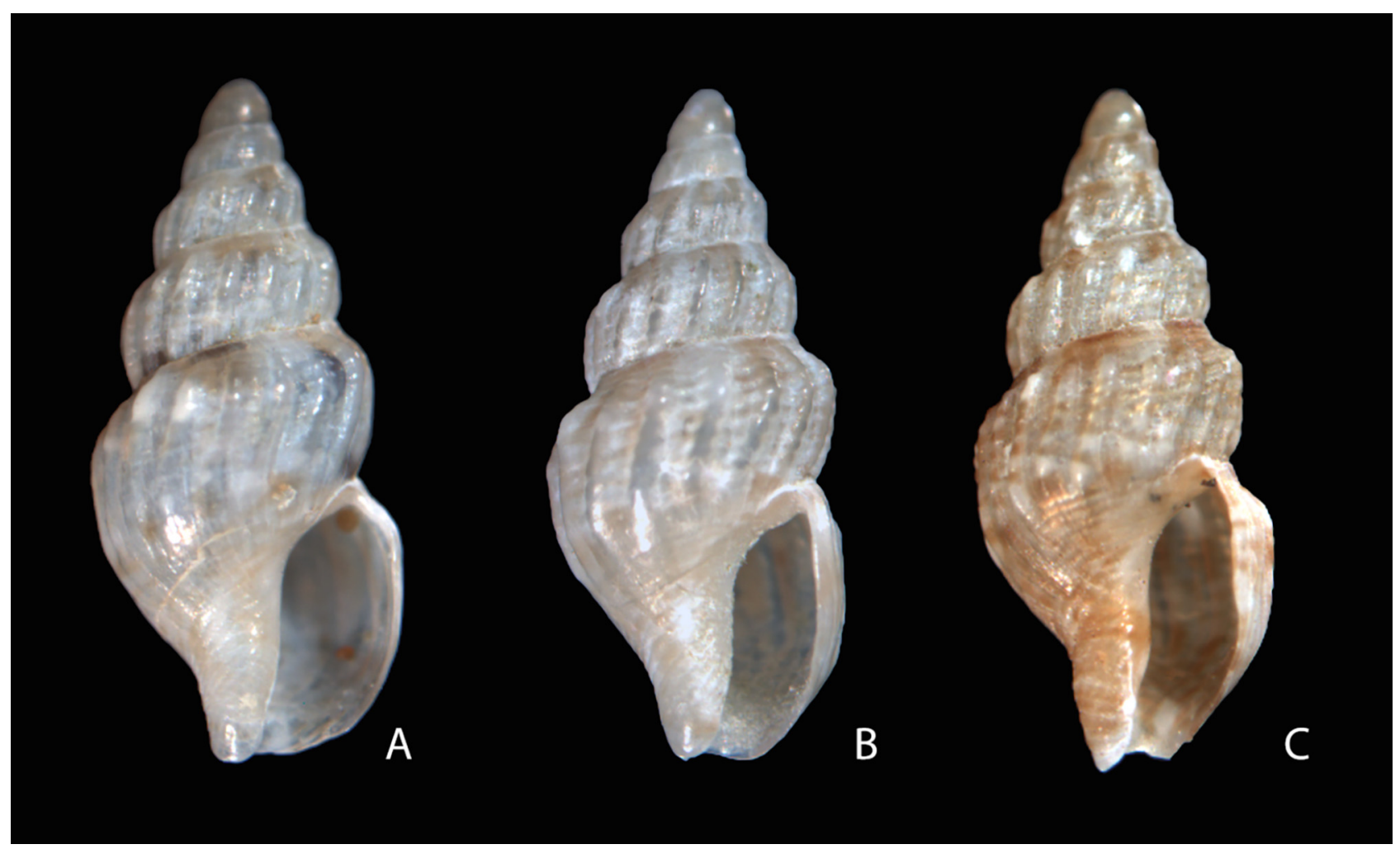

FIGURE 13. A-C. Zanassarina guadalupensis n. sp. A. 15-37 m, S side, Guadalupe Island, Baja California (LACM station 1965-42); A. (LACM 3617, holotype), $4.3 \mathrm{~mm}$. B. (LACM 3618, paratype), $4.6 \mathrm{~mm}$. C. 9-21 m, NW side Guadalupe Island, Baja California, (LACM 3622, paratype, LACM station 1972-121), $4.2 \mathrm{~mm}$. 
Description. Shell 4-5 mm long, with 4 to 4.5 teleoconch whorls. Chunky shell with shouldering produced by sharp, oblique axials that end abruptly below the suture; shallow spiral grooves also present overall. Sculpture not developed on first whorl. Color and pattern variable, generally off-white with narrow brown spirals between axials and white and brown blotches on them. Aperture edge thin, no denticles on labial edge or columella. Protoconch narrowly conic, generally brown, with 2-2.25 whorls and no velar sinus.

Distribution. Guadalupe Island, Baja California. 10 to $40 \mathrm{~m}$. Uncommon.

Remarks. Relative to $Z$. conspicua, this species has a much thinner, slightly translucent shell, and the whorls have a slightly squared outline. Zanassarina conspicua has a very thick shell with rounded whorls, with the axial ridges projecting much more at the middle of the whorl.

Etymology. Named for Guadalupe Island, where it has been found.

\title{
Zanassarina insularis $\mathrm{n} . \mathrm{sp}$.
}

(Figure 14A-C)

Type material. Holotype: LACM 3623 (LACM station 1972-121), 9-21 m, NW side of Guadalupe Island, Baja California $\left(29^{\circ} 11.3^{\prime} \mathrm{N}, 118^{\circ} 15.2^{\prime} \mathrm{W}\right)$, J.H. McLean, 28 September 1972, $4.1 \mathrm{~mm}$ (Fig. 14C). Paratypes: 1 spm LACM 3624 (LACM station 1933-141), 25 fms [46 m], Pilot Rock, N end of Guadalupe Island, Baja California (Fig. 14B); 1 spm, LACM 3625 (LACM station 1957-2), 17-23 fms [31-42 m], Guadalupe Island, Melpomene Cove, E of Zapato Islet, C.L. Hubbs, 18 December 1957; 2 spms, LACM 3626 (LACM station 1972-120), 40-90 ft. [12-27 m], Afeura Island, Adentro, $5 \mathrm{fm}$ bank \& basalt arches, SW side Guadalupe Island, J.H. McLean, 27 September 1972; 19 additional spms from type locality, LACM 3627 (LACM station 1972-121) (Fig. 14A); 2 spms from LACM 3628 (LACM station 1971-93), 13-15 m, Five Fathom Bank, 4 miles SW of SE tip of Cedros Island, Baja California $\left(27^{\circ} 59.0^{\prime} \mathrm{N}, 115^{\circ} 12.7^{\prime} \mathrm{W}\right), 4.9 \mathrm{~mm} ; 1 \mathrm{spm}$ from S side Piedra Colorada, SW tip Cedros Island (LACM 3629, LACM station 1972-115).

Description. Shell 4-5 mm long, with 4-5 well-rounded teleoconch whorls, tall spire; width to length ratio about 0.4; sculpture of axial ridges overrun by well-separated spiral cords, forming low beads at intersection; some specimens essentially clathrate, others with spirals stronger, one or two stronger cords at periphery. Color white to tan with light brown mottling, spiral cords white in some. Columella smooth, labial edge slightly thickened but without labial or parietal denticles. Protoconch conical, light brown, with 1.75-2 whorls, shallow velar sinus.

Distribution. Found from four lots around Guadalupe Island, and two lots from Cedros Island, Baja California. 9 to $46 \mathrm{~m}$. Rare.

Etymology. Given that this species has only so far been seen from the offshore islands of Guadalupe and Cedros, the name refers to its insular character.

Remarks. This species is rather variable in terms of color, pattern and shell sculpture, but no characters could be found that would justify splitting it further. The species is similar to Decipifus dictynna (Dall, 1919) from further south, which should probably be transferred to Zanassarina, but the new species has stronger spiral and axial sculpture.

\author{
Zanassarina penicillata (Carpenter, 1864) \\ (Figure 14 D-F) \\ ?Anachis penicillata Carpenter, 1864: 537, 664, not figured; 1865: 398. Type. Lectotype USNM 15576 (designated by Palmer \\ 1958: pl. 23, fig. 4). San Diego, Santa Barbara, Catalina Island, California. $5.3 \mathrm{~mm}$ long. \\ Columbella (Anachis) minima Arnold, 1903: 237, pl. 9, fig. 8 [non Columbella minima Tenison-Woods, 1878]. Type. Holotype \\ USNM MO 162558. San Pedro, Pleistocene. \\ Columbella (Anachis) arnoldi Dall, 1908: 250 [new name for C. minima Arnold].
}

Description. Shell 5-6 mm long, with five relatively flat-sided teleoconch whorls, slightly shouldered; sculpture of prominent, rounded axial ribs variably overrun by spiral cords. Color translucent white with pale brown patches, dense spiral and diagonal brown lines. No labial or parietal denticles. Protoconch conical, offwhite to tan, with $1.75-2$ whorls.

Distribution. San Simeon, California, to Asuncion Island, Baja California. Low intertidal to $30 \mathrm{~m}$. Common. 


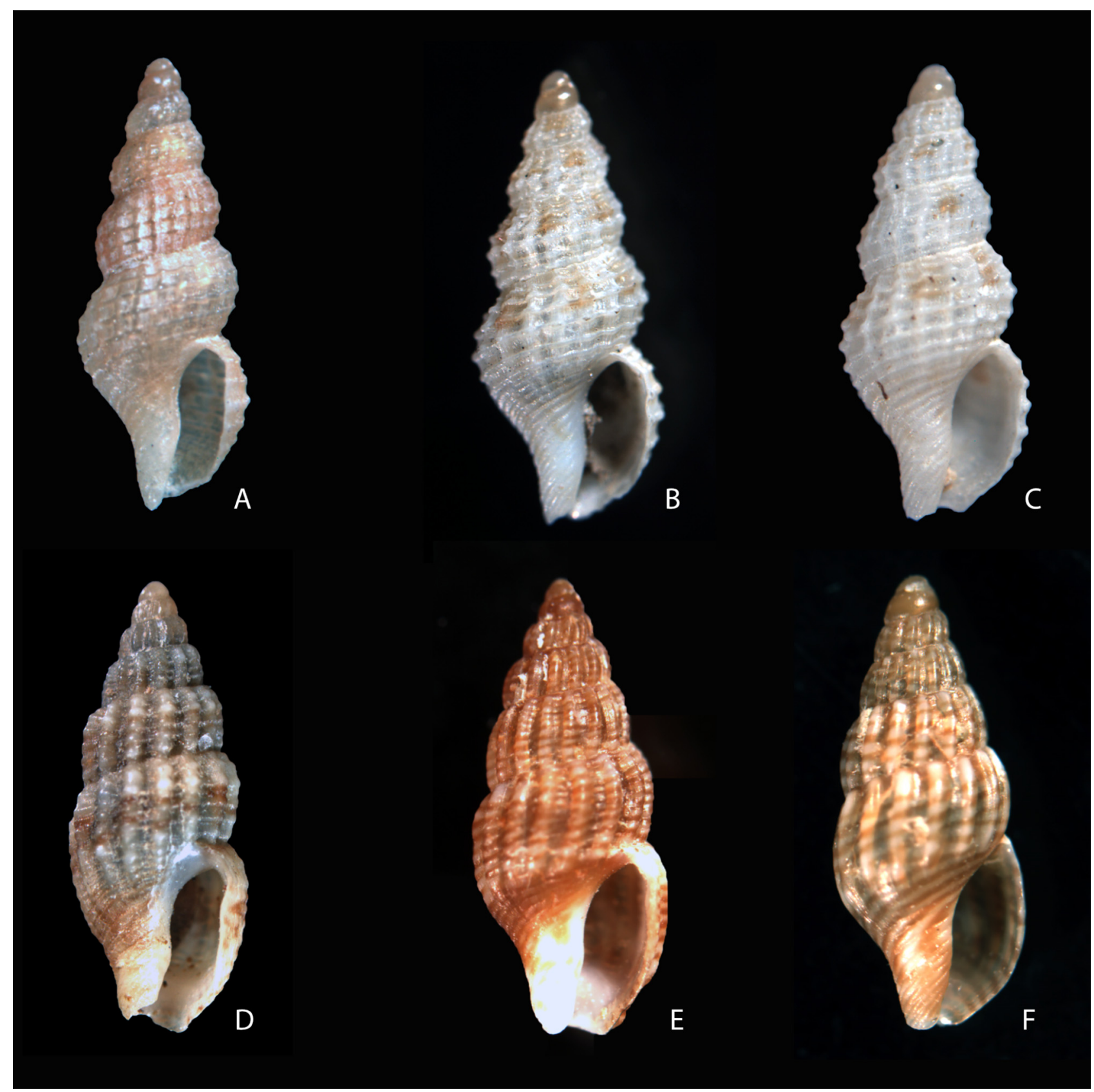

FIGURE 14. A-C. Zanassarina insularis n. sp. A. 9-21 m, Guadalupe Island, Baja California (LACM 3627, paratype, LACM station 1972-121), 4.4 mm. B. 25 fms [46 m], Pilot Rock, N end of Guadalupe Island, Baja California (LACM 3624, paratype, LACM station 1933-141), 4.8 mm. C. 9-21 m, NW side of Guadalupe Island, Baja California (LACM 3623, holotype, LACM station 1972-121), 4.1 mm. D-F. Zanassarina penicillata (Carpenter, 1864). D. Palos Verdes, California (LACM 64073), 5.9 mm. E. 60-100 ft [18-30 m], Rocas Pinaculo, $1 \mathrm{mi} \mathrm{W}$ of San Benito Island, Baja California. 5.6 mm (LACM 1972-118.35). F. 60-80 ft [18-24 m], Pyramid Point, SE tip of San Clemente Island, Los Angeles County, California. 4.8 mm (LACM 196929.56).

Remarks. Carpenter gave this species minimal treatment in 1864 (name only on p. 537 and a one-line description on p. 664), then described it more completely in 1865. Some authorities thus erroneously cite the species description date as 1865 . Palmer (1958), in selecting the lectotype, picked the larger of the two syntypes, but did not restrict the type locality from the original three locations Carpenter specified. The sculpture of the shell is fairly variable; axial ribs are almost always well-developed but the spiral sculpture varies from almost nonexistent, to overriding grooves, to narrow strap-like cords. 


\section{Acknowledgments}

A great deal of credit for this manuscript must be given to Jim McLean, because the initial manuscript I received was fairly complete, while admittedly identifying more new species than I could recognize. I would also like to thank the editorial team of Daniel Geiger, Lindsey Groves and Jann Vendetti for inviting me to contribute to finishing this work. Finally, I would like to thank Lindsey Groves for facilitating two visits to LACM to look at the material and then loaning it to me anyway; Dan Geiger for taking some of the photos, and Paul Valentich-Scott at SBMNH for facilitating two visits to Santa Barbara to work in that collection.

\section{References}

Abbott, R.T. (1974) American Seashells, $2^{\text {nd }}$ ed. Van Nostrand Reinhold Co., Princeton. 663 pp.

Adams, C.B. (1852) Catalogue of shells collected at Panama, with notes on synonymy, station and habitat. Annals, Lyceum of Natural History, New York, 5, 229-548. https://doi.org/10.1111/j.1749-6632.1852.tb00129.x

Adams, H. \& Adams, A. (1853) Genera of Recent Mollusca, Arranged according to their Organization. vol. 1. John Van Vorst, London. 484 pp.

Araya, J.F., Catalán, R. \& Aliaga, J.A. (2016) A new deep-water Astyris species (Buccinoidea: Columbellidae) from the southeastern Pacific. Zootaxa, 4139, 140-144. https://doi.org/10.11646/zootaxa.4139.1.11

Arnold, R. (1903) The paleontology and stratigraphy of the marine Pliocene and Pleistocene of San Pedro, California. California Academy of Sciences, Memoirs, 3, 1-420, pls. 1-37.

Bartsch, P. (1918) Two new species of fossil marine shells from California. Proceedings of the Biological Society of Washington, 31, 79-80.

Carpenter, P.P. (1864) Supplementary report on the present state of our knowledge with regard to the Mollusca of the west coast of North America. Report of the British Association for the Advancement of Science, for 1863, 517-686.

Carpenter, P.P. (1865) Diagnoses of new forms of Mollusca from the west coast of North America, first collected by. Col. E. Jewett. The Annals and Magazine of Natural History, ser. 3, 15, 394-399. https://doi.org/10.1080/00222936508681825

Carpenter, P.P. (1866) Descriptions of new marine shells from the coast of California, Part III. Proceedings of the California Academy of Natural Sciences, ser. 1, 3, 207-224.

Chenu, J. C. (1859) Manuel de Conchyliologie et de Paléontologie conchyliologique, vol. 1. Masson, Paris, vii +508 pp., 3707 figs.

Cossmann, M. (1901) Essais de Paléoconchologie Comparée, vol. 4. Cossmann, Paris. 293 pp., 10 pls.

Dall, W.H. (1871) Descriptions of sixty new forms of mollusks from the west coast of North America and the North Pacific Ocean, with notes on others already described. American Journal of Conchology, 7, 93-160, pls. 13-16.

Dall, W.H. (1889) Reports on the results of dredging, under the supervision of Alexander Agassiz, in the Gulf of Mexico (1877-78) and the Caribbean Sea (1879-80), by the U.S. Coast Survey Steamer "Blake,"... XXIX. Report on the Mollusca. Part II. Gastropoda and Scaphopoda. Bulletin of the Museum of Comparative Zoology, Harvard, 18, 1-492, pls. $1-40$.

Dall, W.H. (1890) Scientific results of explorations by the U. S. Fish Commission Steamer Albatross. No. VII. Preliminary report on the collection of Mollusca and Brachiopoda obtained in 1887-'88. Proceedings of the United States National Museum, 12, 219-362. https://doi.org/10.5479/si.00963801.12-773.219

Dall, W.H. (1908) Descriptions of new species of mollusks from the Pacific coast of the United States, with notes on other mollusks from the same region. Proceedings of the U.S. National Museum, 34 (1610), 245-257. https://doi.org/10.5479/si.00963801.34-1610.245

Dall, W.H. (1912) New Californian Mollusca. The Nautilus, 25, 127-129.

Dall, W.H. (1916) Notes on the west American Columbellidae. The Nautilus, 30, 25-29.

Dall, W.H. (August) (1919a) Descriptions of new species of Mollusca from the North Pacific Ocean in the collection of the United States National Museum. Proceedings of the United States National Museum, 56 (2295), 293-371. https://doi.org/10.5479/si.00963801.56-2295.293

Dall, W.H. (December) (1919b) New shells from the northwest coast. Proceedings of the Biological Society of Washington, 32 , 249-252.

Dall, W.H. (1921) Summary of the marine shellbearing mollusks of the northwest coast of America, from San Diego, 
California, to the polar sea, mostly contained in the collection of the United States National Museum, with illustrations of hitherto unfigured species. United States National Museum Bulletin, 112, 1-217, pls. 1-22.

https://doi.org/10.5962/bhl.title.114713

Dunker, W. (1877) Mollusca nonnulla nova maris Japonici. Malakozoologische Blätter, 24, 67-75.

Gaskoin, J.S. (1852) Descriptions of 20 species of Columbellidae, and on species of Cypraea. Proceedings of the Zoological Society of London, part 19, 2-14.

https://doi.org/10.1111/j.1096-3642.1851.tb01124.x

Gould, A.A. (1840) Dr. A.A. Gould read descriptions of the following species of shells. Sillimans's American Journal of Science and Arts, 38, 196-197.

Gould, A.A. (1850) [On the shells collected by the United States Exploring Expedition.] Proceedings of the Boston Society of Natural History, 3, 169-172.

Gould, A.A. (1852) Mollusca and Shells. Vol. 12. United States Exploring Expedition during the years 1839-1842 under the command of Charles Wilkes, U.S.N. Sherman, Philadelphia, ix +510 pp.

Gould, A.A. (1856) Atlas [Plates to vol. 12]. Sherman, Philadelphia, 16 pp., 52 pls. https://doi.org/10.5962/bhl.title.61454

Gould, A.A. (1860) Descriptions of new shells collected by the United States North Pacific Exploring Expedition under Captains Ringgold and Rodgers. Proceedings of the Boston Society of Natural History, 7, 382-384.

Gould, A.A. \& Carpenter, P.P. (1857) Descriptions of shells from the Gulf of California, and the Pacific coasts of Mexico and California. Proceedings of the Zoological Society of London, part 24, 198-208.

Grant, U.S., IV, \& Gale, H.R. (1931) Catalogue of the marine Pliocene and Pleistocene Mollusca of California and adjacent regions. Memoirs of the San Diego Society of Natural History, 1, 1-1036, pls. 1-32.

Gulbin, V.V. (1983) New species of the genus Astyris (Gastropoda, Hamiglossa, Anachidae) from the Commander Islands Shelf (Bering Sea). Zoologičeskij Žurnal, 62, 1575-1577.

Hertlein, L.G. \& Strong, A.M. (1951) Mollusks from the west coast of Mexico and Central America. Part 10. Zoologica, 36, 67-120, pls. 1-11.

Hinds, R.B. (1844-1845) The Zoology of the Voyage of H.M.S. Sulphur, under the Command of Captain Sir Edward Belcher ... during 1836-1842. Smith, Elder \& Co., London, Mollusca, 1-48, pls. 1-14 [1844], 49-72, pls. 15-21 [1845].

Johnson, R.I. (1964) The Recent Mollusca of Augustus Addison Gould. United States National Museum Bulletin, 239, 1-182, pls. $1-45$. https://doi.org/10.5479/si.03629236.239

Kaicher, S.D. (1984) Card Catalogue of World-wide Shells. Pack \#38-Columbellidae Part II. S.D. Kaicher, St. Petersburg, Florida, cards [i-ii], 3776[bis]-3875[bis], 3876-3881.

Kaicher, S.D. (1985) Card Catalogue of World-wide Shells. Pack \#42 - Columbellidae Part Ill. S.D. Kaicher, St. Petersburg, Florida, Cards [i-ii), 4200-4305.

Keen, A.M. (1971) Sea Shells of Tropical West America, second edition. Stanford University Press, Stanford. 1064 pp.

McLean, J.H. (1996) The Prosobranchia. Pp. i-v, 1-160 in P.H. Scott, J.A. Blake \& A.L. Lissner (eds). Taxonomic atlas of the Benthic Fauna of the Santa Maria Basin and Western Santa Barbara Channel. Vol. 9. The Mollusca Part 2 - The Gastropoda. Santa Barbara Museum of natural History, Santa Barbara.

McLean, J.H. \& Kanner, P. (2005) On the color form (or species?) lineata Stearns, 1873, of Amphissa versicolor Dall, 1871, with illustrations of other named forms of the species (Gastropoda: Columbellidae). The Festivus, 37, 111-115.

Menke, K.T. (1828) Synopsis Methodica Molluscorum. Generum Omnium et Specierum Earum quae in Museo Menkeano Adservantur, cum Synonymia Critica et Novarum Specierum Diagnosibus. Pyrmonti. 91 pp. https://doi.org/10.5962/bhl.title.13182

MolluscaBase (2018) Aesopus Gould, 1860. Accessed through: World Register of Marine Species at: http:// www.marinespecies.org/aphia.php? $\mathrm{p}=$ taxdetails\&id=225496 on 2018-06-29

Monsecour, K. \& Köhler, F. (2006) Annotated list of columbellid types held in the Malacological Collection of the Museum für Naturkunde, Berlin (Mollusca, Caenogastropoda, Columbellidae). Mitteilungen aus dem Museum für Naturkunde in Berlin, 82, 282-306. https://doi.org/10.1002/mmnz.200600015

Mörch, O.A.L. (1859) Note sur les dents linguales du genre Columbella Lamarck. Journal de Conchyliologie, 7, $254-262$.

Oldroyd, I.S. (1927) The Marine Shells of the West Coast of North America, Vol. II, pt. I. Stanford University Press, Stanford. 297 pp., 29 pls.

Oldroyd, T.S. (1925) The fossils of the lower San Pedro fauna of the San Pedro cut, San Pedro, California. Proceedings of the United States National Museum, 65, 1-39. https://doi.org/10.5479/si.00963801.65-2535.1

Olsson, A.A. \& Harbison, A. (1953) Pliocene Mollusca of Southern Florida, with special reference to those from North Saint 
Petersburg. The Academy of Natural Sciences of Philadelphia Monograph, 8, 1-457, pls. 1-65.

Palmer, K.V.W. (1958) Type specimens of marine Mollusca described by P.P. Carpenter from the West coast (San Diego to British Columbia). The Geological Society of America, Memoir, 76, i-vi, 1-376, pls. 1-35.

Pilsbry, H.A. \& Lowe, H.N. (1932) West Mexican and Central American mollusks collected by H.N. Lowe, 1929-31. Proceedings of the Academy of Natural Sciences of Philadelphia, 84, 33-144, pls. 1-17.

Radwin, G.E. (1977) The family Columbellidae in the Western Atlantic. The Veliger, 19, 403-417.

Radwin, G.E. (1978) The family Columbellidae in the Western Atlantic Part IIb. - the Pyreninae. The Veliger, 20, $328-344$.

Reeve, L.A. (1846-1847) Monograph of the genus Buccinum. Conchologica Iconica, vol. 3, 10 pls.

Reeve, L.A. (1858-1859) Monograph of the genus Columbella. Conchologica Iconica, vol. 11, 37 pls.

Risso, A. (1826) Histoire Naturelle des Principales Productions de l'Europe Méridionale et Particulièrement de Celles des Environs de Nice et des Alpes Maritimes. Paris, Levrault. Vol. 4, iv +439 pp., 12 pls.

Skoglund, C. (1992) Additions to the Panamic Province Gastropod (Mollusca) Literature 1971 to 1992. The Festivus, 24, supplement, i-viii, 1-169.

https://doi.org/10.5962/bhl.title.129425

Smith, C.R., Kukert, H., Wheatcroft, R.A., Jumars, P.A. \& Deming, J.W. (1989) Vent fauna on whale remains. Nature, 341, 2728. https://doi.org/10.1038/341027a0

Smith, E.A. (1880) Descriptions of six new species of shells from Vancouver Island. Annals and Magazine of Natural History, ser. 5, 6, 286-289. https://doi.org/10.1080/00222938009458939

Stearns, R.E.C. (1873) Descriptions of new marine mollusks from the west coast of North America. Proceedings of the California Academy of Sciences, ser. 1, 5, 78-82, pl. 1.

Turner, R.D. (1956) The eastern Pacific marine mollusks described by C.B. Adams. Occasional Papers on Mollusks, Museum of Comparative Zoology, Harvard, 2(20), 21-135, pls. 5-21.

Williamson, M.B. (1892) An annotated list of the shells of San Pedro Bay and vicinity, with a description of two new species by W.H. Dall. Proceedings of the United States National Museum, 15, 179-220, pls. 19-23.

Wilson, B. (1994) Australian Marine Shells, part 2, neogastropods. Odyssey Publishing, Kallaroo, Western Australia. 370 pp.

Woodring, W.P. (1928) Marine Miocene mollusks from Bowden, Jamaica. Gastropods and discussion of results. Carnegie Institution of Washington, Publication, 385, 1-460, pls. 1-40. 